\title{
Curcumin: reclaiming the lost ground against cancer resistance
}

\author{
Siraj Shaikh ${ }^{1,2}$, Javed Shaikh ${ }^{1,2}$, Yusufi Sadia Naba1 ${ }^{1}$, Kailas Doke ${ }^{1,2}$, Khursheed Ahmed $^{1,2}$, Mujahid Yusufi ${ }^{1,2}$ \\ 1Post-Graduate Department of Chemistry and Research Center, Abeda Inamdar Senior College of Arts, Science and Commerce \\ (Affiliated to SPPU), Pune 411001, India. \\ ${ }^{2}$ Advanced Scientific Research Laboratory, Azam Campus, Pune 411001, India.
}

Correspondence to: Dr. Mujahid Yusufi, Post Graduate Department of Chemistry and Research Center, Abeda Inamdar Senior College of Arts, Science and Commerce (Affiliated to SPPU), 2390-B, K.B. Hidayatullah Road, Azam Campus, Camp, Pune 411001, India. E-mail: YusufiMujahid@azamcampus.org

How to cite this article: Shaikh S, Shaikh J, Naba YS, Doke K, Ahmed K, Yusufi M. Curcumin: reclaiming the lost ground against cancer resistance. Cancer Drug Resist 2021;4:298-320. http://dx.doi.org/10.20517/cdr.2020.92

Received: 7 Oct 2020 First Decision: 10 Dec 2020 Revised: 15 Dec 2020 Accepted: 6 Jan 2021 Available online: 19 Jun 2021

Academic Editor: Godefridus Peters Copy Editor: Monica Wang Production Editor: Jing Yu

\begin{abstract}
Curcumin, a polyphenol, has a wide range of biological properties such as anticancer, antibacterial, antitubercular, cardioprotective and neuroprotective. Moreover, the anti-proliferative activities of Curcumin have been widely studied against several types of cancers due to its ability to target multiple pathways in cancer. Although Curcumin exhibited potent anticancer activity, its clinical use is limited due to its poor water solubility and faster metabolism. Hence, there is an immense interest among researchers to develop potent, water-soluble, and metabolically stable Curcumin analogs for cancer treatment. While drug resistance remains a major problem in cancer therapy that renders current chemotherapy ineffective, curcumin has shown promise to overcome the resistance and resensitize cancer to chemotherapeutic drugs in many studies. In the present review, we are summarizing the role of curcumin in controlling the proliferation of drug-resistant cancers and development of curcumin-based therapeutic applications from cell culture studies up to clinical trials.
\end{abstract}

Keywords: Curcumin, drug-resistant cancer, signaling pathways, clinical trials

\section{INTRODUCTION}

Challenges posed by cancer have always been a notch higher than the advancements in chemotherapy. Treatment of cancer remains one of the most important concerns worldwide including United States. As

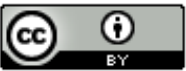

(C) The Author(s) 2021. Open Access This article is licensed under a Creative Commons Attribution 4.0 International License (https://creativecommons.org/licenses/by/4.0/), which permits unrestricted use, sharing, adaptation, distribution and reproduction in any medium or format, for any purpose, even commercially, as long as you give appropriate credit to the original author(s) and the source, provide a link to the Creative Commons license, and indicate if changes were made.

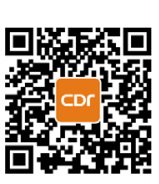


per the estimates of American Chemical Society, United States may witness 1,806,590 new cancer cases and 606,520 deaths caused by cancer in $2020^{[1]}$. Currently employed chemotherapeutic regimens offer highly desired respite against cancer; nevertheless the resistance to anticancer drugs is the problem, which needs to be addressed on priority. Research in the area of drug resistance has revealed the complexity of the process that may involve alteration of drug targets, genetic differences and tumor heterogeneity. Drug resistance can be induced through numerous mechanisms such as increased drug efflux, suppression of apoptosis, altered drug metabolism, amplification of oncogene and epigenetic factors ${ }^{[2]}$. A drug-resistant cancer is labelled as Multi-Drug Resistant (MDR) cancer when it demonstrates resistance to two or more anticancer drugs. Identification of multi-drug resistance warrants better therapeutic strategies for successful cancer treatment.

In recent times, natural products have received immense attention due to their low toxicity, ability to negotiate with multiple targets implicated in cancer as well as their efficacy against elimination of cancer stem cells. Natural products-inspired novel lead compound account for almost 50\% over the past few decades $^{[3]}$. The naturally occurring compounds, especially phytochemicals and their synthetic conjugates ${ }^{[4-6]}$ have been widely investigated to explore the therapeutic potential for the prevention and treatment of cancer, whereas recent studies have also established their role in chemo-sensitizing cancer cells to overcome $\mathrm{MDR}^{[7-12]}$.

Curcumin is one such phytochemical which has been extensively studied. It targets multiple cancers and is reported to sensitize cancer drugs in MDR cancers. Although the compound showed promising activity in pre-clinical studies, its clinical use is limited due to limited water solubility and faster metabolism. To overcome this, several analogs of curcumin have been synthesized and tested pre-clinically in search of better therapeutic activity ${ }^{[13,14]}$. A large number of reported studies and increasing interest of researchers have reinforced the claim of curcumin being one of the most sought after natural product in the fight against cancer.

Curcumin, structure [Strucuture 1, Figure 1], is a polyphenolic compound of up to $5 \%$ present in turmeric $^{[15]}$. Turmeric is a traditional medicine and also used as a food additive. In the South Asian region, it is recognized as an important remedy in Ayurveda and Unani system of medicine and it belongs to the Zingiberaceae family ${ }^{[16]}$. Curcumin as a phytochemical, has been widely explored for its therapeutic potential through in vitro and in vivo investigations. It has been shown to possess biological activity against a large spectrum of physiological conditions, which include antioxidant ${ }^{[17-20]}$, chemo-protective ${ }^{[21-23]}$, anti$\operatorname{diabetic}^{[24-26]}$ and anti-proliferative activity against cancer cells ${ }^{[27-31]}$.

\section{DEVELOPMENTS IN CHEMOTHERAPY}

Progress and milestones achieved in cancer chemotherapy in almost eight decades are historical in terms of their impact. Starting from a very non-specific cytotoxic agent, nitrogen mustard [Strucuture 2, Figure 1] in the early $1940 \mathrm{~s}^{[32]}$ to revolutionizing studies on vinca alkaloids like vinblastine [Strucuture 3, Figure 2] in $1968^{[33]}$, which shifted the focus towards the use of natural products against various types of cancers. Although accidental, a remarkable discovery of estrogen receptor-specific activity of tamoxifen [Strucuture 4, Figure 2] in 1980 was another accomplishment of chemotherapy ${ }^{[34]}$ which led to more investigations directed towards target specific designing of anti-cancer agents. More insights into system biology led to the development of monoclonal antibody (MAB) for cancer treatment and consequential FDA approval to rituximab ${ }^{[35]}$ against B-Cell Lymphoma in 1997. The same year witnessed the arrival of 2-phenylaminopyrimidine derivative showing inhibitory effects on Abl-protein tyrosine kinase, which is responsible for the promotion of cell growth signaling pathway ${ }^{[36]}$. 
<smiles>COc1cc(/C=C/C(=O)CC(=O)/C=C/c2ccc(O)c(OC)c2)ccc1O</smiles>

1<smiles>CN(CCCl)CCCl</smiles>

Figure 1. Structure of Curcumin and Nitrogen Mustard

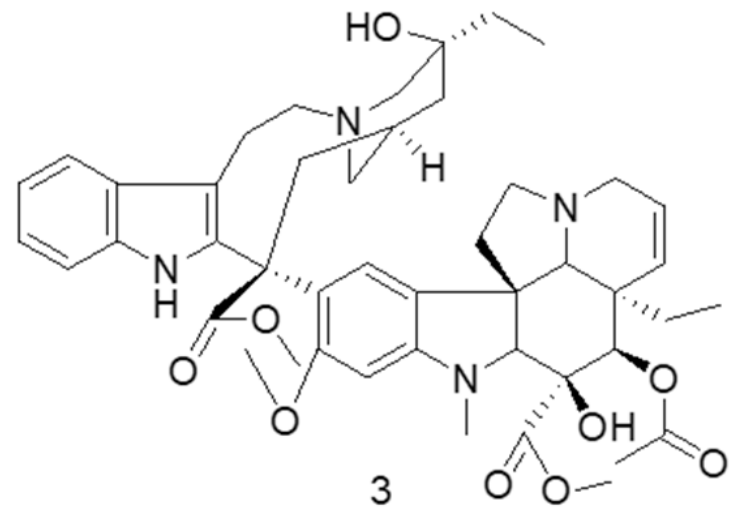<smiles>CC/C(=C(\c1ccccc1)c1ccc(OCCN(C)C)cc1)c1ccccc1</smiles>

Figure 2. Structure of Vinblastine and Tamoxifen<smiles>Cc1ccc(NC(=O)c2ccc(CN3CCN(C)CC3)cc2)cc1Nc1nccc(-c2cccnc2)n1</smiles>

Figure 3. Structure of Imatinib

In 2001, the said derivative, which is now known as imatinib [Strucuture 5, Figure 3], obtained the recognition of the first FDA approved tyrosine kinase inhibitor, for the treatment of chronic myeloid leukemia. However, despite these commendable advancements in chemotherapy, cancer treatment remains a serious challenge due to drug-resistant cancers.

\section{CANCER DRUG RESISTANCE}

The cancers not responding to chemotherapeutic treatment are termed as drug-resistant cancers. Cancer cells may get directly or indirectly protected against chemotherapy through different factors and means like epigenetics ${ }^{[37-41]}$, increased drug efflux by ATP-driven drug transporters ${ }^{[42-44]}$, DNA-damage repair ${ }^{[45,46]}$, antiapoptotic mechanism $^{[47-49]}$ and epithelial-mesenchymal transition $(\mathrm{EMT})^{[50-52]}$.

\section{Curcumin against resistant breast cancer}

There have been systematic efforts to identify drug-resistant cancers and formulate therapeutic solutions. The investigations involving Curcumin in this pursuit have resulted in promising results so far. Adriamycin resistant MCF- $7_{\mathrm{ADR}}$ and Tumor Necrosis Factor resistant BT- $20_{\mathrm{TNF}}$ breast cancer cell lines showed $15 \%$ 
$( \pm 6 \%)$ and $8 \%$ cell viability respectively against curcumin at a dose of $1 \mu \mathrm{g} / \mathrm{ml}(2.7 \mu \mathrm{M})^{[53]}$. The same study claimed that curcumin exhibited the growth inhibitory effect on estrogen-dependent MCF-7 and T-47D as well as estrogen-independent SK-BR3 cell lines at lower concentrations, and arrested the majority of cells in the G2/M phase and inhibition of ornithine decarboxylase (ODC) activity. A comparative study of the effect of curcumin on human mammary epithelial (MCF-10A) and MDR breast carcinoma (MCF$7 / \mathrm{TH}$ ) cell lines reported that the $\mathrm{IC}_{50}$ value of curcumin against MCF-10A was 3.5 times higher than that of MCF-7/TH although cytometric analysis showed equal accumulation of curcumin in both cell lines and it is well complemented with the apoptosis studies where $40 \mu \mathrm{M}(24 \mathrm{hr})$ concentration of curcumin led $1.8 \%$ of MCF-10A cells into apoptosis while $46.6 \%$ of MDR, MCF-7/TH went into apoptosis under similar conditions, which in terms of considering the collateral damages is a significant observation ${ }^{[54]}$. In an investigation undertaken by Meiyanto et al. ${ }^{[55]}$, doxorubicin-resistant breast cancer cell lines MCF-7/Dox cells with over-expression of HER2 were tested against doxorubicin $\left(\mathrm{IC}_{50}=7\right)$ and curcumin $\left(\mathrm{IC}_{50}=80 \pm\right.$ 2.39) separately and in combination. The MTT Assay showed that curcumin at half of its $\mathrm{IC}_{50}$ concentration in combination with doxorubicin at half of its $\mathrm{IC}_{50}$ concentration, decreased the percentage cell viability of MCF-7/Dox cell lines by almost $80 \%$, and this synergistic action of combinatorial treatment-induced cell death, evident through the accumulation of more cells in sub-G1 and G1 phase as compared to the percentage of cells when they were treated separately by doxorubicin and curcumin. Efficacy of curcumin against resistant breast cancer cell lines was demonstrated through SRB assay on MCF-7, antiestrogenresistant MCF-7/LCC2 and MCF-7/LCC9 cell lines, which revealed IC $_{50}$ values of curcumin to be 9.7, $12.2 \mu \mathrm{M}$ and $11.34 \mu \mathrm{M}$ respectively against these cancer cell lines and colony formation for each cell line was suppressed by curcumin at a concentration of $30 \mu \mathrm{M}$. These activities of curcumin were attributed to lowering of anti-apoptotic expressions and inhibition of NF- $\kappa B$ and Akt/mTOR pathway ${ }^{[56]}$. The photosensitization of cancer cells by curcumin towards photodynamic therapy (PDT) has been covered by Muniyandi et al. ${ }^{[57]}$ and apoptosis is the mode of action in majority of the works cited in the review. The adriamycin resistant breast cancer cell line MCF-7/ADR was found to be equally affected as MCF-7 cells (Cell viability 50\%) on 45 minutes preincubation with curcumin $(7.5 \mu \mathrm{M})$ followed by irradiation with blue light $\left(450 \mathrm{~nm}, 100 \mathrm{~mW} / \mathrm{cm}^{2}\right)$ for $5 \mathrm{~min}$ and subsequent $24 \mathrm{~h}$ incubation ${ }^{[58]}$.

\section{Curcumin against resistant colorectal cancer}

In vitro studies on human colorectal cancer cell line HCT116 and its isogenic 5-fluorouracil (5-FU) resistant cell line HCT116R in a 3D model showed that curcumin potentiated the anti-proliferative activity of 5-FU against these cell lines through apoptosis and inhibition of formation of colonies, with suppression

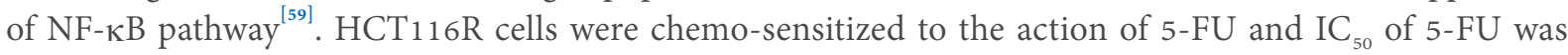
recorded as $0.1 \mu \mathrm{M}$ when it was used in combination with $5 \mu \mathrm{M}$ concentration of curcumin. This synergistic combination increased the percentage of apoptotic cells by $56 \%$ in HCT116R cell lines. The molecular role of curcumin in apoptosis has already been shown in another report where it intensified the downregulation of anti-apoptotic BclxL and cell division favoring cyclin D1 protein caused by 5-FU in HCT116 and HCT116+ch3 (Complemented with chromosome 3) cell lines and inhibiting activation of IkB $\alpha$ kinase and its phosphorylation ${ }^{[60]}$. Chemo-sensitization of drug-resistant cancer cell lines by curcumin, towards a particular chemotherapeutic agent, has been reported in one more investigation involving oxaliplatin sensitive human colorectal adenocarcinoma HT29 Cells and its oxaliplatin resistant derived sub-line HTOXAR3 cells, which showed that combination of curcumin and oxaliplatin almost reversed the oxaliplatin resistance in HTOXAR3 cell line with oxaliplatin $\mathrm{IC}_{50}$ reaching to $10.6 \pm 2.2 \mu \mathrm{M}$ which is fairly comparable to HT29 cell line whereas $\mathrm{IC}_{50}$ has been noted as $8.45 \pm 1.6 \mu \mathrm{M}^{[61]}$. Mechanistic aspects in this investigation showed that curcumin effected reversal of oxaliplatin resistance at $20 \mu \mathrm{M}$ concentration against the HTOXAR3 cell line through inhibition of oxaliplatin-induced activation of NF- $\kappa$ B pathway, which otherwise would have led to an increase in anti-apoptotic expressions like survivin and Bcl-2. 


\section{Curcumin against resistant leukemia}

Daunorubicin resistant CD $34^{+}$acute myeloblastic leukemia cell lines KG1a and Kasumi-1 showed inhibition in growth and clonogenicity to curcumin treatment in dose and time-dependent manner ${ }^{[62]}$. In this study, Curcumin showed an $\mathrm{IC}_{50}$ value of $35.7 \mu \mathrm{M}$ against KG1a $23.5 \mu \mathrm{M}$ against Kasumi-1 on $96 \mathrm{hr}$ exposure and completely stopped colony formation at $20 \mu \mathrm{M}$ concentration. The mechanistic investigations reflected the role of curcumin in activation of Caspase-3, down-regulation of Bcl-2 mRNA expression and reduction in mitochondrial membrane potential in addition to remarkable morphological changes like cell shrinking and nuclear condensation, which are characteristics of apoptosis. Another drug-resistant leukemia cell line HL60 responded to curcumin with 50\% growth inhibition at $30 \mu \mathrm{M}$ concentration ${ }^{[63]}$. Cell cycle studies in this experiment established apoptosis as the mechanism of action of curcumin and arrest of the cell cycle in the S-phase was also reported in the same study.

\section{Curcumin against resistant lung cancer}

Human non-small cell lung cancer cell line A549, which showed 50\% cell viability at a high dose of 10,000 $\mathrm{U}$ of interferon (IFN)-alpha (IFN $\alpha$ ), was investigated to understand the resistivity of these cells against such a higher concentration of IFNa ${ }^{[64]}$. On treatment with one-tenth of the $\mathrm{IC}_{50}$ value, the $\mathrm{A} 549$ cells

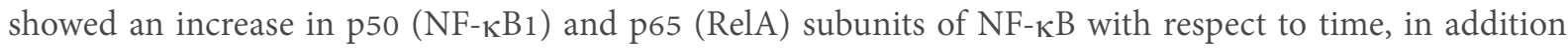
to an increase in Cox-2 expression. On pretreatment with curcumin, a dose-dependent decrease in these subunits was noticed in Western Blot Analysis and a decrease in Cox-2 expression was also noted. Thus, curcumin showed a remarkable decrease in NF- $\mathrm{KB}$ and Cox-2 activity in a dose-dependent manner with a maximum dose of $50 \mu \mathrm{M}$ in IFN $\alpha$ resistant A549 cell lines and it increased the vulnerability of cells towards the cytotoxic activity of IFN $\alpha$. The lower water solubility of curcumin has led to the use of methods like micelles and nanocapsules for effective permeation and release. Adriamycin resistant A549/ADR lung cancer cell line showed a reversal of resistance to doxorubicin on treatment with polymeric micelles loaded with doxorubicin and curcumin ${ }^{[65]}$.

\section{Curcumin against resistant prostate cancer}

In many of the references cited in this review, the induction of apoptosis has been one of the modes of action of curcumin. PI3/Akt pathway, which promotes cell growth, proliferation, and survival, is inhibited by curcumin ${ }^{[6,667]}$. Mechanistic studies, carried out at subtoxic concentrations of curcumin in LNCap cells showed that pretreatment with curcumin sensitized the cells towards tumor necrosis factor-related apoptosis-inducing ligand (TRAIL) through inhibition of the NF- $\kappa B$ pathway of cell survival ${ }^{[68]}$. Castrationresistant prostate cancer cell (CRPC) line $\mathrm{C} 4-2 \mathrm{~B}$, showed a promising response to chemo-sensitization towards remarkably low concentration dose of $10 \mathrm{nM}$ docetaxel on pretreatment with a combination of $5 \mu \mathrm{M}$ curcumin and $5 \mu \mathrm{M}$ nelfinavir ${ }^{[69]}$, commendably without much adverse effect on primary prostate epithelial cells. The molecular study revealed an increase in pro-apoptotic markers caused by endoplasmic reticulum (ER) stress and decrease in expressions associated with PI3K/AKT survival pathway like phosphorylated-AKT. This in vitro finding was complemented with in vivo studies in the xenograft model. Docetaxel resistant CRPC lines PC3 and DU145 when treated with curcumin and curcumin nanoparticles prepared by emulsification showed cytotoxic effects of curcumin ${ }^{[70]}$. The $\mathrm{IC}_{50}$ values of curcumin in nanoparticle form against Docetaxel-resistant CRPC PC3 and DU145 cells were $5.0 \pm 0.7 \mu \mathrm{M}$ and $12.1 \pm$ $1.1 \mu \mathrm{M}$ respectively, while free curcumin showed $\mathrm{IC}_{50}$ values of $20.9 \pm 0.3 \mu \mathrm{M}$ and $27.1 \pm 1.4 \mu \mathrm{M}$ against these resistant cell lines respectively, underlining the fact that better delivery methods can potentiate the cytotoxic action of curcumin. A summary of in vitro activities of curcumin against various cancer cell lines has been compiled in Table 1 .

\section{CURCUMIN AGAINST CANCER STEM CELLS PATHWAYS}

Cancer stem cells (CSCs) are those cells from the heterogeneous population of a tumor, which are capable of self-renewal ${ }^{[69]}$, aggressive proliferation, differentiation and cologenicity ${ }^{[71-73]}$. The aggressive 
Table 1. In vitro activity of Curcumin (Cur) alone and in combination

\begin{tabular}{|c|c|c|c|c|}
\hline Cancer type & Cell line & $\begin{array}{l}\text { Concentration in } \mu \mathrm{M} \text { of Cur and other } \\
\text { agents if any }\end{array}$ & $\begin{array}{l}{ }^{\star} \text { Cell viability as } \\
\% \text { of control }\end{array}$ & Ref. No. \\
\hline \multirow[t]{15}{*}{ Breast cancer } & MCF-7 & 2.7 Cur & $9 \pm 1$ & {$[53]$} \\
\hline & MCF-7 ${ }_{A D R}$ (Adriamycin-Resistant) & 2.7 Cur & $15 \pm 6$ & \\
\hline & BT-20 & 2.7 Cur & $1 \pm 0$ & \\
\hline & BT-20 $\mathrm{TNF}_{\mathrm{TN}}$ (Tumor Necrosis Factor-Resistant) & 2.7 Cur & $8 \pm 0$ & \\
\hline & MCF-10A (Normal Mammary Epithelial) & $55.0 \pm 3.53$ Cur & 50 & {$[54]$} \\
\hline & MCF-7/TH (Multidrug-Resistant) & $17.5 \pm 1.76$ Cur & 50 & \\
\hline & MCF-7 & $109 \pm 1.915$ Cur & 50 & {$[55]$} \\
\hline & MCF-7/Dox (Doxorubicin-Resistant) & $80 \pm 2.39$ Cur & 50 & \\
\hline & MCF-7/Dox (Doxorubicin-Resistant) & 7 Doxorubicin & 50 & \\
\hline & MCF-7/Dox (Doxorubicin-Resistant) & 40 Cur + 3.5 Doxorubicin & 80 & \\
\hline & MCF-7 & 9.7 Cur & 50 & {$[56]$} \\
\hline & MCF-7/LCC2 (Antiestrogen-Resistant) & 12.2 Cur & 50 & \\
\hline & MCF-7/LCC9 (Antiestrogen-Resistant) & 11.34 Cur & 50 & \\
\hline & MCF-7 & 7.5 Cur + PDT & 50 & {$[58]$} \\
\hline & MCF-7/ADM (Adriamycin-Resistant) & 7.5 Cur + PDT & 50 & \\
\hline \multirow{18}{*}{$\begin{array}{l}\text { Colorectal } \\
\text { Cancer }\end{array}$} & HCT116 & 9 Cur & 50 & [59] \\
\hline & HCT116R (5 FU-Resistant) & 5 Cur & 50 & \\
\hline & HCT116 & $55-\mathrm{FU}$ & 50 & \\
\hline & HCT116R (5 FU-Resistant) & 10 5-FU & $>80$ & \\
\hline & HCT116 & $5 \mathrm{Cur}+0.15-\mathrm{FU}$ & 50 & \\
\hline & HCT116R (5 FU-Resistant) & $5 \mathrm{Cur}+25-\mathrm{FU}$ & 50 & \\
\hline & HCT116 & 20 Cur & 50 & {$[60]$} \\
\hline & $\begin{array}{l}\text { HCT116+ch3 (Complemented with } \\
\text { chromosome 3) }\end{array}$ & 5 Cur & 50 & \\
\hline & HCT116 & $55-\mathrm{FU}$ & 50 & \\
\hline & $\begin{array}{l}\text { HCT116+ch3 (Complemented with } \\
\text { chromosome 3) }\end{array}$ & $15-\mathrm{FU}$ & 50 & \\
\hline & HCT116 & 5 Cur $+15-\mathrm{FU}$ & 50 & \\
\hline & $\begin{array}{l}\text { HCT116+ch3 (Complemented with } \\
\text { chromosome 3) }\end{array}$ & $5 \mathrm{Cur}+0.15-\mathrm{FU}$ & 50 & \\
\hline & HT29 & $8.5 \pm 1.6$ Oxaliplatin & 50 & {$[61]$} \\
\hline & НT29 & $9 \pm 1.4$ Cur & 50 & \\
\hline & HT29 & $4.6 \pm 1.1$ Cur $+3.24 \pm 0.7$ Oxaliplatin & 50 & \\
\hline & $\begin{array}{l}\text { HTOXAR3 (Oxaliplatin Resistant Derived } \\
\text { Sub-line of HT29) }\end{array}$ & $8.3 \pm 0.8$ Cur & 50 & \\
\hline & $\begin{array}{l}\text { HTOXAR3 (Oxaliplatin Resistant Derived } \\
\text { Sub-line of HT29) }\end{array}$ & $30.2 \pm 4.2$ Oxaliplatin & 50 & \\
\hline & $\begin{array}{l}\text { HTOXAR3 (Oxaliplatin Resistant Derived } \\
\text { Sub-line of HT29) }\end{array}$ & 10 Cur + 10.6 \pm 2.2 Oxaliplatin & 50 & \\
\hline \multirow[t]{3}{*}{ Leukemia } & KG1a & 35.7 Cur & 50 & [62] \\
\hline & Kasumi-1 & 23.5 Cur & 50 & \\
\hline & HL60 & 30 Cur & 50 & {$[63]$} \\
\hline \multirow[t]{4}{*}{ Lung Cancer } & A549 & 1.89 Doxorubicin & 50 & {$[65]$} \\
\hline & A549 & 2.6 Cur + 1.1 Adriamycin & 50 & \\
\hline & A549/ADR (Adriamycin-Resistant) & 69.7 Doxorubicin & 50 & \\
\hline & A549/ADR (Adriamycin-Resistant) & 98.5 Cur + 41.7 Adriamycin & 50 & \\
\hline \multirow{8}{*}{$\begin{array}{l}\text { Prostate } \\
\text { Cancer }\end{array}$} & $\mathrm{C} 4-2 \mathrm{~B}$ & 0.59 Docetaxel & 50 & [69] \\
\hline & $\mathrm{C} 4-2 \mathrm{~B}$ & 30 Nelfinavir & 50 & \\
\hline & $\mathrm{C} 4-2 \mathrm{~B}$ & 59 Cur & 50 & \\
\hline & $\mathrm{C} 4-2 \mathrm{~B}$ & 0.01 Docetaxel+5 Nelfinavir+5 Cur & ffi30 & \\
\hline & PC3 & $21.4 \pm 0.8$ Cur & 50 & {$[70]$} \\
\hline & PC3 Docetaxel-Resistant & $20.9 \pm 0.3$ Cur & 50 & \\
\hline & DU145 & $19.5 \pm 1.1$ Cur & 50 & \\
\hline & DU145 Docetaxel-Resistant & $27.1 \pm 1.4$ Cur & 50 & \\
\hline
\end{tabular}

$\star \%$ Cell viability as compared to control (control is $0 \%$ inhibition) 
characteristic properties of CSCs make them a bigger challenge than other neoplastic cells. Severe combined immunodeficiency disease (SCID) mice show new tumor growth when transplanted with $\mathrm{CSCs}^{[74]}$. An understanding of CSCs with respect to their properties, which are common to other cells and differentiating characters, which make them distinguished targets can lead to sophisticated strategies to deal with the CSCs. It has been shown that CSCs also show some regularity pathways similar to normal cells like Wnt $/ \beta$-catenin ${ }^{[75,76]}$, Sonic Hedgehog $(\mathrm{Hh})^{[77,78]}$, Notch $^{[76]}$, and Hippo ${ }^{[79,80]}$ Signaling pathways.

\section{Curcumin against Wnt/ $\beta$-catenin pathway}

The role of the Wnt signaling pathway in cell multiplication and differentiation ${ }^{[81,82]}$ is well established. The irregular activation of Wnt pathway has been implicated in human cancer because of anomalous increase in the nuclear concentration of $\beta$-catenin and consequential activation of cancer associated genes ${ }^{[83-85]}$. $\beta$-catenin has been linked to various cancers including colorectal carcinoma, non-small cell lung cancer, breast cancer and prostate cancer ${ }^{[86]}$. Regulation of hyper-activated Wnt signally is an important strategy to control cancer involving this pathway. Human non-small cell lung cancer (NSCLC) cell line A427 and A549 on treatment with curcumin up-regulated micro RNA miR-192-5p and inhibited the cell growth and migration with the deactivation of Wnt $/ \beta$-catenin pathway ${ }^{[87]}$. Similar deactivation by curcumin has been reported in medulloblastoma through regulation of the Wnt/ $\beta$-catenin pathway with down-regulation of $\beta$-catenin and Cyclin D ${ }^{[88]}$. Curcumin induced apoptosis in HCT-116 cells and derived cell lines without p53 or p21 genes at $20 \mu \mathrm{M}$ with $67 \%$ to $88 \%$ cells arrested in G2/M phase and curcumin pretreatment inhibited transcriptional activity of the $\beta$-catenin/Tcf-Lef complex and activated Caspase- $3^{[89]}$. Mechansitic insights from other investigations have consolidated the understanding of role of curcumin in inhibition of $\mathrm{Wnt} / \beta$-catenin pathways in various cancers ${ }^{[90,91]}$.

\section{Curcumin against hedgehog signaling pathway}

Sonic Hedgehog (SHH) signaling pathway involves transduction of signals directed at regulation of growth of multicellular organisms ${ }^{[92,93]}$. The growth and development in an embryo is a complex phenomenon and impaired SHH signaling is known to reflect in birth defects and complications pertaining to cancer growth $^{[94]}$ in mammals.

Curcumin has been shown to regulate GLI1 mRNA and GLI1 reporter activity in prostate cancer cell lines and in vivo model and GLI1 is known to be an important transcription factor in Hedgehog pathway ${ }^{[95]}$. Significant outcomes were noticed in transforming growth factor- $\beta 1$ (TGF- $\beta 1$ )-stimulated PANC- 1 cell lines, on treatment with curcumin $(30 \mu \mathrm{M} / \mathrm{mL})$, which not only inhibited the cell proliferation, invasion and migration but also reversed the EMT caused by TGF- $\beta 1$. The down-regulated expressions of Shh and GLI1 in PANC-1 cells can be attributed to inhibition of Shh Signaling pathway by curcumin ${ }^{[94]}$. Many other studies on molecular mechanism of action have reported the reversal of EMT by curcumin through inhibition of Shh pathway ${ }^{[96-98]}$. Bladder cancer stem cells (BCSCs) UM-UC-3 and EJ, showed deactivation of the sonic hedgehog (Shh) signaling on treatment with $50 \mu \mathrm{M}$ concentration of curcumin and increase in pro-apoptotic expressions of Bax and cleaved Caspase- $3^{[99]}$. At the same concentration of curcumin, these cells considerably lost the capacity to form spheres and a higher percentage of cells was found in the $G_{0} /$ $\mathrm{G}_{1}$ phase. Shh protein and other downstream expressions in the hedgehog pathway like GLI1 and PTCH1, were found to be decreased in human primary medulloblastoma cells on treatment with curcumin ${ }^{[100]}$.

\section{Curcumin against notch signaling pathway}

Notch signaling pathway is directly involved with cell proliferation and differentiation. Aberrant changes in this pathway lead to cancer and related features including drug resistance and tumor growth $^{[101,102]}$. Gamma $(\gamma)$-secretase (GS) is an important component of Notch signaling and its inhibition is implicated in suppression of cancer growth, inhibition of tumor formation and subjugation of cancer stem cells ${ }^{[103,104]}$. Curcumin has been shown to restrain Notch pathway in esophageal cancer by suppressing GS components 
Nicastrin and Presenilin-1 ${ }^{[105]}$. Notch signaling is known for enabling self-renewal and survival of cancer stem cells ${ }^{[106]}$. Curcumin has been shown to down-regulate the activated Notch-1 signaling human umbilical vein endothelial cells (HUVECs) exposed to hydrogen peroxide-induced cellular oxidative stress $^{[107]}$. In vivo investigations on Sprague Dawley rats consuming high-fat diet showed that curcumin not only lowered the visceral fat, cholesterol and low-density lipoprotein but also suppressed the Notch-1 protein in liver cells ${ }^{[108]}$. The photosensitizing potential of curcumin in induction of apoptosis, inhibition of cell proliferation and regulation of Notch signaling has been demonstrated in cervical cancer cell line Me180. The cells incubated for $6 \mathrm{~h}$ with $1 \mu \mathrm{M}$ solution of DAPT $\{\mathrm{N}-[\mathrm{N}-(3,5$-difluorobenzene acetyl-1propionyl)]-(S)-phenylglycine tert-butyl\}, which is a Notch receptor blocker and $\gamma$-secretase inhibitor in combination with $2.5 \mu \mathrm{M}$ solution of curcumin were irradiated with laser $\left(445 \mathrm{~nm}, 100 \mathrm{~J} / \mathrm{cm}^{2}\right)$. After $24 \mathrm{~h}$, the group receiving curcumin and DAPT along with photodynamic treatment (PDT) showed increased apoptotic cell death and a remarkable inhibition rate of $79.27 \%$ in Notch 1 mRNA expression whereas the group receiving DAPT alone and curcumin-PDT showed $39.99 \%$ and $32.33 \%$ inhibition rate respectively ${ }^{[109]}$.

\section{CURCUMIN: INROADS INTO IN VIVO}

The in vitro performance of any given compound is important for preliminary progress in drug development, however in vivo activity strengthens its claim of bearing the desirable therapeutic potential. Curcumin has been widely explored for its pharmaceutical potential for in vitro and in vivo investigations with remarkable outcomes. The concerns regarding poor water solubility $(0.6 \mu \mathrm{g} / \mathrm{mL})$ have been addressed through various methods to increase the bioavailability for in vivo studies. Successful efforts have been made through preparation of various formulations like nanoparticles ${ }^{[110-113]}$, liposomes ${ }^{[114,115]}$ and combinatorial treatment ${ }^{[116-19]}$ of curcumin with anticancer agents. It is important to note that free curcumin has also shown commendable activity during in vivo studies despite its limitations of lower water solubility, stability and bioavailability but the formulated curcumin or curcumin in combinatorial treatment has exceeded the performance of isolated treatment of free curcumin in majority of the cases.

Thus, a formulation overcoming challenges of solution stability, bioavailability, targeted delivery and lowest possible toxicity is much sought after in the case of every drug and curcumin is also not an exception in this regard. Many efforts have been successful in this direction and they have led to appreciable in vivo performance. A nano-suspension prepared from $\mathrm{d}$ - $\alpha$-Tocopherol polyethylene glycol 1000 succinate and curcumin increased the water solubility by more than 400 times $^{[120]}$ and the lyophilized nano-suspension, produced fine powder which could be again reconstituted by the addition of water.

The in vivo findings are not only important to ascertain the desirable pharmaceutical effect in a more natural environment but also to understand the pharmacodynamics, pharmacokinetics, toxic effects on vital organs like heart; kidney; liver and spleen while providing insights on mechanistic aspects of mode of action of a drug on histological and immunohistochemical examination of tissues. Careful recording of physiological and behavioral changes in the in vivo studies, changes in total body weight and survival time are important aspects of pre-clinical studies. The pre-clinical in vivo studies are crucial in the case of any molecule to prove its eligibility as a suitable candidate for advanced investigations.

\section{Curcumin against brain cancer in vivo}

Subcutaneous and intracerebral orthotopic model of Human glioma U-87 cells in athymic mice on intraperitoneal dose of curcumin $(120 \mathrm{mg} / \mathrm{kg} /$ day $)$ showed less than $50 \%$ decrease in median tumor volume in subcutaneous xenograft while in the orthotopic model, the average life span of group receiving similar dose increased by $12 \%$ as compared to the control group ${ }^{[121]}$. In Female SCID mice xenograft model, human primary medulloblastoma cells (DAOY) were subcutaneously injected and after 30 days, the animals were given oral gavage of curcumin $(1 \mathrm{mg} / \mathrm{kg})$ dissolved in corn oil ${ }^{[122]}$. The tumor growth inhibition in curcumin treated group was significantly noticeable as compared to the control group. The 
group of Smo/Smo transgenic medulloblastoma mice receiving oral dose of curcumin was reported to have a median survival time of 192 days as compared to the control group, which had a median survival time of 144 days. This observation is in agreement with earlier claims of ability of curcumin to cross Blood Brain Barrier ${ }^{[123,124]}$. Mechanistic insights in xenografted human medulloblastom D425 cells in athymic mice showed overexpression of $\mathrm{p} 65$ subunit of NF- $\mathrm{KB}$ and the curcumin treated group showed tumor growth inhibition which can be partially attributed to down regulation of $\mathrm{p} 65$ subunit $^{[125]}$.

In another in vivo investigation, human glioblastoma U87-MG cells-inoculated nude mice were administered with $100 \mathrm{mg} / \mathrm{kg}$ per day of curcumin in DMSO in Phosphate Buffer Saline through intratumoral injections. After seven days, significant decrease in tumor size was observed in curcumin treated group. Microscopic examination post Acridine Orange staining showed increased acidic vesicular organelles in curcumin treated cells with intact nuclei, pointing towards curcumin-induced autophagy being responsible for cell deaths ${ }^{[126]}$.

\section{Curcumin against breast cancer in vivo}

In the xenograft model of triple-negative human breast cancer MDA-MB-231 lines, curcumin showed reduction in tumor weight in a dose dependent manner and the most effective dose was reported as $200 \mu \mathrm{g} / \mathrm{kg}$ of curcumin administered through intraperitoneal injections for 28 days ${ }^{[127]}$. Transmission electron microscope images showed very distinct morphological changes related to apoptotic cell death without significant side effects on the animals. Oral dose of curcumin in combination with naringenin $(20 \mathrm{mg} / \mathrm{kg}$ each) received by Swiss albino mice, transplanted with murine mammary Ehrlich ascites carcinoma (EAC) cells, resulted in reduction in the formation of new blood vessels in peritoneal and inner skin linings with reduction $(80 \%)$ of total number of cells $/ \mathrm{mL}$ in ascites fluid ${ }^{[128]}$. Athymic mice xenograft model of human triple-negative breast cancer MDA-MB-231 cells showed significant decrease in angiogenesis, cell proliferation and tumor size on treatment with $300 \mathrm{mg} / \mathrm{kg} /$ day intraperitoneal (i.p.) dose of curcumin ${ }^{[129]}$. Another xenograft model of triple negative breast cancer MBCDF-T cells in nude mice on combinatorial treatment of calcitriol ( $0.25 \mu \mathrm{g}$ in $100 \mu \mathrm{L}$ i.p., once a week) and curcumin (40 mg/kg daily in drinking water) showed inhibition of vascularization and tumor growth ${ }^{[130]}$.

Phosphorylated calixarene (POCA4C6)-encapsulated curcumin on intra-tumoral injection [providing $(29.2 \mathrm{mg} / \mathrm{kg})]$ showed strong inhibition of tumor growth in xenografted triple negative Breast cancer cell line BT-549 with indication of substantial early apoptosis as compared to the groups treated with empty micelles and free curcumin. Increased bioavailability through micelle-encapsulated delivery of curcumin was established with the help of increased fluorescence showing increased curcumin-accumulation in tumor ${ }^{[131]}$. MCF-7 xenograft subcutaneously inoculated in BALB/c nude mice when treated with a combination of paclitaxel and curcumin encapsulated in biodegradable polymeric nanoparticles prepared from tri-block copolymer of poly ( $\varepsilon$-caprolactone)-poly(ethylene glycol)-poly( $\varepsilon$-caprolactone) showed highest tumor growth inhibition with insignificant loss in total body weight and highest survival percentage as compared to that of control group and groups treated individually with paclitaxel and curcumin ${ }^{[132]}$.

Human Breast cancer BT-474 cells with overexpression of HER-2, xenografted in athymic nude mice showed promising results with decreased mean tumor size as compared to other groups on treatment with $45 \mathrm{mg} / \mathrm{kg}$ dose of curcumin twice/week in combination with herceptin $(2 \mathrm{mg} / \mathrm{kg}$ ) once a week on intraperitoneal injection for four weeks ${ }^{[133]}$. A unique conjugate of curcumin was reported with membrane associated protein, Annexin A2 for the treatment of xenograft model of highly invasive Breast cancer cell line MCF10CA1a, which also showed overexpression of Annexin A2. PLGA nanoparticles loaded with Annexin A2-Curcumin conjugate at a dose of $20 \mathrm{mg} / \mathrm{kg}$ every alternate day for 32 days, decreased the tumor volumes by $44 \% \pm 5.2 \%$ along with remarkable inhibition of neovascularization ${ }^{[134]}$. A subcutaneous xenograft model of triple negative breast cancer cell line $4 \mathrm{~T} 1$ in Female Balb/c mice showed 27\% reduction 
in the initial size of tumor on treatment with Curcumin loaded nanocompositen (NC) of $\mathrm{Fe}_{3} \mathrm{O}_{4}$ core and $\mathrm{SiO}_{2}$ shell on intra-tumoral injection of $40 \mu \mathrm{L}$ of $\mathrm{NC}(20 \mu \mathrm{g}$ curcumin, $0.46 \mathrm{mg} / \mathrm{mL})$ followed by irradiation with a blue diode laser $(450 \mathrm{~nm}, 150 \mathrm{~mW} / \mathrm{cm} 2)$ for 3 minutes and then second irradiation with near infrared laser $(808 \mathrm{~nm}, 0.5 \mathrm{~W} / \mathrm{cm} 2)$ for 7 minutes on every alternate day for two weeks ${ }^{[135]}$. The observations are significant in this study considering availability of fewer treatment options in the case of triple negative breast cancer.

\section{Curcumin against Cervical Cancer In Vivo}

Exosomes-extra cellular vesicles - as drug carriers are being considered for in vivo administrations. A formulation of curcumin with bovine milk-derived exosomes (Exocur) with a curcumin load of $18 \%-24 \%$ increased the bioavailability in various tissues. Human Cervical cancer (CaSki) xenograft in immunodeficient athymic female nude mice on treatment with $20 \mathrm{mg} / \mathrm{Kg}$ of Exocur decreased the tumor volume by $61 \%$ while free curcumin showed no effect on tumor size ${ }^{[136]}$. The same study reported no toxic effect of Exocur on mice on oral administration for two weeks at a dose of $2.5 \mathrm{mg} / \mathrm{kg}$.

Liposomal curcumin (intraperitoneal dose of $25 \mathrm{mg} / \mathrm{kg}$ on alternated days) sensitized the human cervical cancer HeLa cell xenograft in non-obese diabetic SCID mice and 3-methylcholanthrene-induced cervical multistage squamous carcinoma in Swiss albino mice to Paclitaxel (intraperitoneal dose of $10 \mathrm{mg} / \mathrm{kg}$, twice in a week) treatment. The combinatorial treatment of curcumin and paclitaxel reduced the tumor incidence by 76 percent as compared to control group whereas groups individually treated with curcumin and paclitaxel showed reduction of $40 \%$ and $56 \%$ respectively. Mechanistic observations showed that NF- $\kappa \mathrm{B}$ activation caused by paclitaxel was suppressed on combinatorial treatment of curcumin and helped in inhibition of tumor growth in xenograft tumors ${ }^{[137]}$.

\section{Curcumin against colorectal cancer in vivo}

The BALB/c nude mice xenograft model of human colorectal carcinoma cells HCT116, where HCT116 cells were separately transfected with pre-mRNA processing factor $4 \mathrm{~B}$ (PRP4) and pre-mRNA processing factor 8 (PRP8), on treatment with intraperitoneally-injected $50 \mathrm{mg} / \mathrm{kg}$ of curcumin showed that the overexpressed PRP8 could not resist the curcumin-induced apoptosis as evident from tumor size and Western blot analysis showing overexpressed PRP8. PRP4 was hypothesized to resist the curcumin-induced apoptosis due to its kinase domain on the basis of earlier investigations and tumor growth did not get affected, which was also complemented with overexpressed PRP4 shown in western blot analysis. Further confirmations of hypothesis were made after deletion of kinase domain from PRP4, where curcumin successfully regulated tumor size in $\mathrm{P}_{4} \mathrm{~K}^{-/} \mathrm{HCT} 116$ xenograft. These mechanistic insights implicated the role of kinase domain of PRP4 along with apoptosis inducing potential of curcumin ${ }^{[138]}$.

Curcumin bonded to human serum albumin (HSA) nanoparticles not only showed 300 times increased water solubility but also showed 14 times higher accumulation in tumor on intravenous administration after 1 hour as compared to that of free curcumin in the HCT1116 xenograft. 66\% tumor growth inhibition by curcumin loaded HSA nanoparticles as compared to $18 \%$ tumor growth inhibition by free curcumin can per partially attributed to increased solubility and bioavailability of curcumin due to curcumin-HAS nanoparticle formulation ${ }^{[139]}$. A remarkable formulation of turmeric with phosphatidylcholine (1:4), which is called Mervia, showed five times increased bioavailability of curcumin as compared to free curcumin. Mervia was granted a US Patent (No. WO2013176555A1) in 2017 and recognized under improved complexes and compositions containing curcumin category. A combinatorial treatment of Mervia mixed with diet and biweekly intraperitoneal injection of oxaliplatin $(7.5 \mathrm{mg} / \mathrm{kg})$ in human colorectal cancer HCT116 cells xenograft for three weeks in female nude mice showed highest decrease of $51 \%$ in tumor volume $\mathrm{e}^{[140]}$. Sub-toxic doses of curcumin $(50 \mathrm{mg} / \mathrm{kg})$ in combination with oxaliplatin $(25 \mathrm{mg} / \mathrm{kg})$, when administered every alternate day for 22 days in the human LoVo colorectal cells xenograft model in 
nude mice, caused remarkable suppression of tumor growth with signatures of apoptotic cell deaths. This investigation underlines the significance of combinatorial therapeutic regimens, where tumor growth can be inhibited without collateral damages ${ }^{[141]}$.

Curcumin loaded on polymeric Nanomicelle (OA-400), prepared from poly ethylene glycol 400 (PEG400) and oleoyl chloride, exhibited remarkable chemo-preventive activity against carcinogenic azoxymethaneinduced colon cancer (subcutaneous dose of $15 \mathrm{mg} / \mathrm{kg}$ of azoxymethane) in male Wistar rats on pretreatment before administration of azoxymethane. Examinations after a period of 18 weeks showed that the number of tumors and size (33\% of control) were considerably less in the group pre-treated with curcumin-loaded Nanomicelle as compared to the control group and group pre-treated with free curcumin. The control group showed highest number of tumors with significantly larger dimensions as compared to other two groups ${ }^{[142]}$. However, safety concerns related to toxicity of OA-400 have not been addressed in this work in details. Administration through oral gavage of combinatorial doses of the formulation of essential turmeric oil with curcumin and tocotrienol-rich-fraction of mixture of isomera of vitamin $\mathrm{E}$ $(5 \mathrm{mg} / \mathrm{kg}$ and $2 \mathrm{mg} / \mathrm{kg}$ respectively) in $100 \mu \mathrm{L}$ of sesame oil in the HCT-116 xenograft in severe combined immunodeficient (SCID) mice showed nearly 3 -fold decrease in tumor size at the end of 40 days as compared to the control group with 7 to 8 fold increase in bioavailability ${ }^{[143]}$.

\section{Curcumin against gastric cancer in vivo}

BGC-823 xenograft tumors on combinatorial treatment of curcumin with 5-FU and oxaliplatin showed remarkable inhibition of tumor growth through apoptotic pathway suggested through elevated expressions of caspase-3, 8 and 9 as compared to the group receiving combination of 5-FU with oxaliplatin and the group receiving curcumin alone ${ }^{[144]}$. Another xenograft model of gastric cancer cell line SGC-7901 showed involvement of apoptotic cell death as the underlying mechanism induced by curcumin ${ }^{[145]}$. One more BGC-823 xenograft, on treatment with curcumin encapsulated in Pluronic F-127 micelle $(25 \mathrm{mg} / \mathrm{kg})$, reduced the tumor volume by $75 \%$ as compared to the control group and almost $50 \%$ as compared to the group receiving $25 \mathrm{mg} / \mathrm{kg}$ of free curcumin ${ }^{[146]}$. The xenograft model of human gastric cancer cell line SGC7901, showed $90.02 \% \pm 5.65 \%$ tumor inhibition rate (calculated from tumor volumes in test and control groups) on co-treatment with etoposide and curcumin loaded on nanostructured lipid nanoparticles. Etoposide and curcumin alone loaded on nanostructured lipid nanoparticles showed $69.13 \% \pm 3.86 \%$ and $66.75 \% \pm 4.1 \%$ tumor inhibition ${ }^{[147]}$.

\section{Curcumin against head and neck cancer in vivo}

$\mathrm{Balb} / \mathrm{c} \mathrm{nu} / \mathrm{nu}$ mice, subcutaneously xenografted with head and neck squamous cell carcinoma (HNSCC) SSC40 tongue cells showed decrease in tumor volume in curcumin-pre-treated group with a dose of $15 \mathrm{mg}$ /day through oral gavage. The pre-treated group showed no development of tumors in 4-nitroquinolineoxide-induced carcinogenic model in oral cavity ${ }^{[148]}$. A study of HNSCC CAL27 cells xenograft in nude mice showed that liposomal curcumin $(50 \mathrm{mg} / \mathrm{kg})$ intravenously administered on alternate days for a period of 35 days resulted in $71.8 \%$ reduction in mean tumor weight in well-established xenograft tumors ${ }^{[149]}$. The study also reported normal appearance of kidney, liver, heart, spleen and lung on histological examination and reduced expression of NF- $\kappa B$ (p65) was noted in the immunohistochemical post-treatment profiling of tumor cells.

2-hydroxypropyl- $\gamma$-cyclodextrin ( $\mathrm{HP} \gamma \mathrm{CD}$ ) inclusion complex-loaded phospholipid liposomes exhibited a very effective delivery of curcumin, which resulted in enhanced antiproliferative activity through apoptotic cell death in human osteosarcoma KHOS xenograft model on intra-tumoral injection of $20 \mu \mathrm{L}$ solution of the said formulation on alternated days for two weeks ${ }^{[114]}$. The 10,000 fold increase in curcumin-water solubility on preparation of inclusion compound with $\mathrm{HP} \gamma \mathrm{CD}$ was reported in the said investigation, which is a remarkable enhancement in terms of addressing concerns regarding lower bioavailability of 
curcumin. Lipid nanoparticles loaded with doxorubicin and curcumin were prepared from biodegradable 1,2-Distearoyl-sn-glycero-3-phosphoethanolamine-Poly(ethylene glycol) (DSPE- PEG) polar lipid. BALB/ c nude mice xenograft of KHOS was intravenously administered for three weeks with a frequency of two administrations each week providing $5 \mathrm{mg} / \mathrm{kg}$ of doxorubicin and $10 \mathrm{mg} / \mathrm{kg}$ of curcumin showed tumor growth inhibition ratio (TGI) of $81.3 \%$, which was calculated as [(Weight of control - Weight of treated) $\div$ Weight of control] $\times 100$. The group receiving only doxorubicin and only curcumin showed TGI of 10.3 and 11.9 respectively ${ }^{[150]}$. Xenograft model of oral squamous cell carcinoma cells HSC-3 in female SCID mice showed decrease of $21 \%$ in tumor volume at the end of study as compared to the initial tumor volume, on treatment with the peptide hydrogel loaded with the combination of curcumin and doxorubicin $(1 \mu \mathrm{M}$ and $0.164 \mu \mathrm{M}$ respectively), while the tumor grew up to $368 \%$ of the initial volume when the combination was administered through solution. This combinatorial treatment of in vivo xenograft model of head and neck cancer showed prevalently apoptotic cell death on histological examination ${ }^{[151]}$. Xenograft model of EC9706, esophageal squamous cell carcinoma (ESCC) showed larger decrease in tumor size in the group treated with $50 \mu \mathrm{M}$ curcumin in combination with $5-\mathrm{FU}(5 \mathrm{mg} / \mathrm{Kg})$ as compared to control group and other group including the groups treated with curcumin and 5-FU alone, indicating the supporting role of curcumin in increasing the 5 -FU-mediated apoptosis ${ }^{[152]}$.

\section{Curcumin against liver cancer in vivo}

Xenograft model of hepatocellular carcinoma $\mathrm{H} 22$ cells in nude male mice, showed better inhibition of tumor growth on daily dose of $100 \mathrm{mg} / \mathrm{kg}$ curcumin through intragastric administration for 2 weeks as compared to control group ${ }^{[153]}$. The subcutaneous tumor xenograft of human hepatocellular carcinoma SMMC-7721 cells in BALB/c nude female mice showed minimum tumor volume and highest tumor inhibitory rate (TIR) of $70 \%$ on combinatorial treatment of curcumin $(56.65 \mathrm{mg} / \mathrm{kg})+5$-FU $(10 \mathrm{mg} / \mathrm{kg})$ as compared to the control ${ }^{[154]}$. Human hepatocellular carcinoma HepG2 cells xenograft tumor in female BALB/c nude mice showed more than 50\% reduction in tumor volume on daily intraperitoneal administration of curcumin $(200 \mathrm{mg} / \mathrm{kg})$ for one month with indications of autophagy ${ }^{[155]}$. Group receiving the combinatorial treatment of metformin $(150 \mathrm{mg} / \mathrm{kg})$ with curcumin $(60 \mathrm{mg} / \mathrm{kg})$ in subcutaneous HepG2 xenograft in nude mice showed 58.3\% inhibition of tumor growth as compared to that of group treated with $150 \mathrm{mg} / \mathrm{kg}$ of metformin and the group receiving only $60 \mathrm{mg} / \mathrm{kg}$ of curcumin ${ }^{[156]}$. The study reported insignificant decrease in total body weight. Orally administered dose $(60 \mathrm{mg} / \mathrm{kg})$ of micellarcurcumin solution in combination with cisplatin (intraperitoneal injection $1 \mathrm{mg} / \mathrm{kg}$ ) showed inhibition of tumor growth in the xenografted model of HC-AFW-1 pediatric hepatocellular carcinoma with increase in concentration of curcumin in different organs and blood ${ }^{[157]}$.

An interesting in vivo experiment showed the antiproliferative action of FDA approved histone deacetylase inhibitor (HDACi)-Trichostatin A (TSA) and combinatorial treatment of curcumin in resisting the Trichostatin-induced metastasis. Xenografted tumor models of human hepatocellular cancer Hep23 cells and human lung cancer $\mathrm{H} 23$ cells in nude mice showed decrease in tumor weight and suppression of metastasis on combinatorial treatment of TSA $(10 \mathrm{mg} / \mathrm{kg} / \mathrm{d})$ and curcumin $(40 \mathrm{mg} / \mathrm{kg} / \mathrm{d})^{[158]}$. The findings rationalize the combinatorial therapeutic regimens in order to suppress the complications arising from the chemotherapeutic agents.

\section{Curcumin against pancreatic cancer in vivo}

A combinatorial treatment of phenethyl isothiocyanate $(0.3 \mathrm{mg})$, which is a dietary compound found in certain vegetables with curcumin $(110.5 \mathrm{mg})$ in $\mathrm{NCr}$ nude mice xenografted with human pancreatic cancer PC-3 cells, showed significant growth inhibition at these lower concentrations at the end of 28 days, starting from the day when xenograft was established properly ${ }^{[159]}$. Another investigation on PC-3 xenograft on treatment with combinatorially encapsulated docetaxel and curcumin in biocompatible lipid polymer nanoparticles prepared from lecithin and PEG-DSPE, providing a dose of $5 \mathrm{mg} / \mathrm{kg}$ docetaxel and $10 \mathrm{mg} / \mathrm{kg}$ 
curcumin, showed TIR of $82.5 \%$, which was the highest as compared to the groups receiving only encapsulated docetaxel $(5 \mathrm{mg} / \mathrm{kg})$ and the group receiving encapsulated curcumin $(10 \mathrm{mg} / \mathrm{kg})$ alone with TIR of $45.2 \%$ and $62.1 \%$ respectively ${ }^{[160]}$.

\section{Curcumin against lung cancer in vivo}

In vivo antitumor activity determined through intra-peritoneal administration of curcumin in a dose of $45 \mathrm{mg} / \mathrm{kg}$ against xenografted 801D highly metastatic human lung cancer, showed greater size reduction in curcumin-treated animals with very clear and intact tumor boundary, which is indicative of significantly decreased tumor invasiveness and the observations were supported by decrease in MMP-2 and MMP9 expressions ${ }^{[161]}$. In another in vivo study, xenograft of $801 \mathrm{D}$ showed a decrease of $41 \%$ in average weight of tumors in curcumin-treated group with clearer boundaries along with weaker staining of Cdc42 as compared to the control group, hinting towards inhibitory effect of curcumin on tumor growth and invasion through suppression of $\mathrm{CDc} 42^{[162]}$.

Orthotopic model of human lung cancer cells (A459) in athymic nu/nu mice was studied for combinatorial treatment of curcumin and doxorubicin loaded on Janus nanoparticles prepared from water-in-oil-in water double-emulsion solvent-evaporation $\operatorname{method~}^{[163]}$. Janus nanoparticles prepared from FDA approved, biodegradable polymer Poly(lactic-co-glycolic acid) (PLGA) and FDA approved lipid, Precirol ${ }^{\circ}$ ATO5, loaded with doxorubicin and curcumin when administered through aerosol inhalation technique showed the tumor size to be of six fold lesser as compared to untreated group after four weeks. In another wellestablished A549 xenograft, synergistic action of docetaxel $(10 \mathrm{mg} / \mathrm{kg})$ and curcumin $(15 \mathrm{mg} / \mathrm{kg})$, showed successful inhibition of tumor growth and metastasis ${ }^{[164]}$.

Xenograft model of gefitinib resistant human lung cancer cell lines CL1-5, A549 and H1975 in SCID mice showed sensitization of cancer cells on combinatorial treatment of gefitinib $(60 \mathrm{mg} / \mathrm{kg})$ and curcumin $(1 \mathrm{~g} / \mathrm{kg})$ with increased tumor growth inhibition as compared to control and other groups ${ }^{[165]}$. The same study reported lesser damage to intestinal mucosa in the group treated with the combinatorial doses, through reduction of p38-activation, known to be caused by gefitinib as reported in other investigations. Xenografted model of gefitinib-resistant Non-Small Cell Lung Cancer cell lines H157 and H1299 on treatment with combination of orally administered curcumin $(1 \mathrm{~g} / \mathrm{kg})$ with gefitinib $(100 \mathrm{mg} / \mathrm{kg})$, exhibited commendable decrease in tumor size indicating chemo-sensitizing potential of curcumin against gefitinibresistant cancer ${ }^{[166]}$. Another combinatorial treatment of Mervia effectively restricted lung metastasis of mammary gland tumor cell line ENU1564 in athymic nude mice ${ }^{[167]}$. Combinatorial treatment of $500 \mathrm{mg} / \mathrm{kg}$ of curcumin suspended in $10 \%$ Tween-80 with $200 \mathrm{mg} / \mathrm{kg}$ of Phospo-sulindac (PS) in the subcutaneous adenocarcinomic human alveolar basal epithelial cell (A549) xenograft resulted in 51\% synergistic inhibition of tumor growth, which was $50 \%$ more effective than the PS treatment alone $e^{[168]}$. Another xenograft model of A549 on treatment with $20 \mathrm{mg} / \mathrm{kg}$ subcutaneous dose of lipid-polymer hybrid nanoformulation-encapsulating curcumin for seven weeks, decreased the tumor volume by $52.1 \%$ and substantial decrease in Annexin A2 as compared to the control group, whereas the group treated with liposomal curcumin showed $32.2 \%$ decrease in tumor volume ${ }^{[169]}$.

\section{Curcumin against Prostate cancer in vivo}

In vivo subcutaneous xenograft of luciferase-expressed human prostate cancer cell line PC-3-Luc, on treatment with $100 \mathrm{mg} / \mathrm{kg}$ of curcumin showed decrease in tumor volume and significant suppression of tumor metastasis. Detailed profiling indicated decreased cellular levels of matriptase, which appears to be responsible for prevention of metastasis ${ }^{[170]}$. PC-3 xenograft in BALB/c nu/nu male mice on daily intraperitoneal injection of curcumin $(100 \mathrm{mg} / \mathrm{kg})$ for 30 days showed significant decrease in tumor growth as compared to the control ${ }^{[171]}$. 


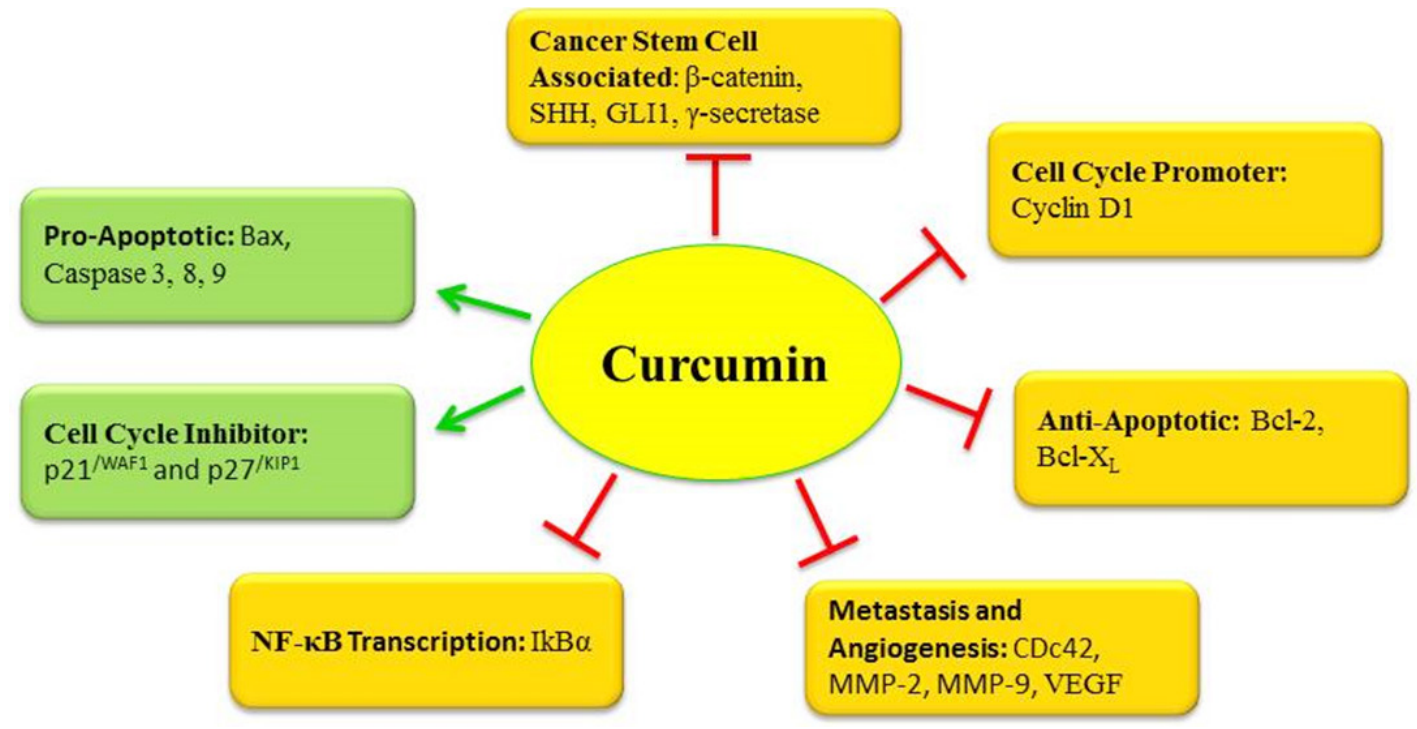

Figure 4. Summarized biological actions of curcumin

Castration-resistant prostate cancer (CRPC) $\mathrm{C} 4-2 \mathrm{~B}$ cells, xenografted in athymic nude mice showed promising result when a combinatorial dose of docetaxel $(10 \mathrm{mg} / \mathrm{kg})$, nelfinavir $(20 \mathrm{mg} / \mathrm{kg})$ and curcumin $(100 \mathrm{mg} / \mathrm{kg})$ was administered intraperitoneally, two weeks after subcutaneous injection of C4-2B cells. The group treated with combinatorial dose showed the suppression of the tumor growth by 3.5 folds as compared to the group treated with docetaxel alone and the vehicle-treated control group showed 22 folds increase in tumor after a period of 4 weeks ${ }^{[69]}$. In another report on human prostate cancer xenograft with $\mathrm{C} 4-2 \mathrm{~B}$ cells in nude mice, intra-tumoral injection of curcumin $(25 \mu \mathrm{g} / \mathrm{mouse})$ in DMSO inhibited the tumor growth by more than $50 \%$ with increased levels of $\beta$-catenin. Silencing of expression of protein kinase D1 (PKD1) by using relevant SiRNA pretreatment before the curcumin dose showed substantially decreased levels of PKD1 expressions as well as lower levels of $\beta$-catenin on the cell surface ${ }^{[172]}$, which points towards probable role of PKD1 in overexpression of $\beta$-catenin and curcumin mediated inhibition of tumor growth. A xenograft model of DU-145, an androgen-independent prostate cancer cell line in SCID mice was treated through oral gavage with a solution of curcumin (equivalent to $5 \mathrm{mg} / \mathrm{kg}$ ), $0.5 \%$ methylcellulose and $0.1 \%$ Tween 80 and it showed $89 \%$ decrease in occurrence of metastatic tumors and remarkable decrease in average range of tumor volumes ${ }^{[173]}$. Balb/c nude mice xenograft model of androgendependent, TNF-related apoptosis-inducing ligand (TRAIL)-resistant human prostate cancer LNCaP cells was investigated to understand the underlying mechanism of growth inhibitory effects of curcumin. Oral injection of combinatorial treatment of curcumin $30 \mathrm{mg} / \mathrm{kg}$ and TRAIL $(15 \mathrm{mg} / \mathrm{kg})$, sensitized the TRAILresistant LNCaP, which was evident through tumor growth inhibition and suppression of metastasis. The immunohistochemical study on xenografted tumors, undertaken after six weeks of combinatorial treatment, showed a significant decrease in expression of MMP-2, MMP-9 and VEGF staining as compared to the control and pronounced expression of cell cycle inhibitors, p2 $1^{/ \mathrm{WAF} 1}$ and $\mathrm{p} 27^{/ \mathrm{KIP} 1}$. Westen blot showed intensified bands of pro-apoptotic Bax-expressions and down-regulated expressions of anti-apoptotic Bcl-2 and $\mathrm{Bcl}-\mathrm{X}_{\mathrm{L}}{ }^{[174]}$. A summary of in vivo activities of curcumin against various cancers has been compiled in Table 2.

\section{CURCUMIN: THE CLINICAL TRIALS}

Curcumin has been recognized and granted FDA approval for clinical trials in determination of dose and as an adjuvant along with the major chemotherapetutic regimen. A clinical trial undertaken on healthy volunteers to understand the pharmacokinetics of curcumin in 12 volunteers (5 Males and 7 
Table 2. In vivo activity of Curcumin (Cur)

\begin{tabular}{|c|c|c|c|c|c|}
\hline $\begin{array}{l}\text { Cancer } \\
\text { type }\end{array}$ & $\begin{array}{l}\text { Cell line used in } \\
\text { xenograft model }\end{array}$ & $\begin{array}{l}\text { Dose in } \mathrm{mg} / \mathrm{kg} \text { body weight and } \\
\text { formulation with other agent if any }\end{array}$ & $\begin{array}{c}\text { Mode of } \\
\text { administration }\end{array}$ & $\begin{array}{l}\star \star \text { Percentage inhibition } \\
\text { in tumor growth as } \\
\text { compared to control }\end{array}$ & Ref. No. \\
\hline \multirow{3}{*}{$\begin{array}{l}\text { Brain } \\
\text { cancer }\end{array}$} & $U-87$ & 120 Cur & Intraperitoneal & 50 & {$[121]$} \\
\hline & DAOY & 1 Cur & Oral gavage & ffi 62 & [122] \\
\hline & U87-MG & 100 Cur & Intra-tumoral & ffi 50 & [126] \\
\hline \multirow{4}{*}{$\begin{array}{l}\text { Breast } \\
\text { cancer }\end{array}$} & MDA-MB-231 & 0.2 Cur & Intraperitoneal & ffi 30 & {$[127]$} \\
\hline & MBCDF-T & 40 Cur +0.00025 calcitriol & Oral + intraperitoneal & ffi 80 & [130] \\
\hline & MCF10CA1a & 20 Conjugate of Annexin A2-Cur & Intravenous & $44 \pm 5.2$ & [134] \\
\hline & $4 \mathrm{~T} 1$ & $\begin{array}{l}\text { Dose in } \mathrm{mg} / \mathrm{kg} \text { body wt. not available } \\
40 \mu \mathrm{L} \text { Cur loaded } \mathrm{Fe}_{3} \mathrm{O}_{4}-\mathrm{SiO}_{2} \text { nano- } \\
\text { composite (Cur } 0.46 \mathrm{mg} / \mathrm{mL} \text { ) }\end{array}$ & Intratumoral & 27 & [135] \\
\hline \multirow[t]{2}{*}{ Cervical } & CaSki & 20 Cur loaded Exosome & Oral gavage & 61 & [136] \\
\hline & HeLa & 25 Cur + 10 Paclitaxel in lysosome & Intraperitoneal & 70 & [137] \\
\hline \multirow[t]{3}{*}{ Colorectal } & HCT1116 & 20 Cur loaded on HSA & Intravenous & 66 & [139] \\
\hline & LoVo & 50 Cur + 25 Oxaliplatin & Intraperitoneal & ffi 43 & [141] \\
\hline & HCT1116 & 5 Cur +2 tocotrienol rich mixture of Vit $\mathrm{E}$ & Oral gavage & ffi 70 & [143] \\
\hline Gastric & BGC-823 & 25 Cur in Pluronic F-127 micelle & Intraperitoneal & 50 & [146] \\
\hline \multirow{3}{*}{$\begin{array}{l}\text { Head and } \\
\text { neck }\end{array}$} & SSC40 & 15 Cur & Oral gavage & ffi 70 & [148] \\
\hline & CAL27 & 50 Cur in Liposome & Intravenous & 71.8 & [149] \\
\hline & KHOS & 10 Cur + 5 Doxorubicin loaded in Nanolipid & Intravenous & 81.3 & [150] \\
\hline \multirow[t]{3}{*}{ Liver } & SMMC-7721 & $56.65 \mathrm{Cur}+105-\mathrm{FU}$ & Intraperitoneal & 70 & [154] \\
\hline & HepG2 & 200 Cur & Intraperitoneal & ffi 50 & [155] \\
\hline & HepG2 & 60 Cur + 150 Metformin & Intraperitoneal + oral & 58.33 & {$[156]$} \\
\hline \multirow[t]{2}{*}{ Pancreatic } & PC-3 & 110.5 Cur + 0.3 phenylisothiocyanate & Intraperitoneal & ffi 76 & [159] \\
\hline & PC-3 & $\begin{array}{l}10 \text { Cur }+5 \text { Docetaxel } \\
\text { loaded on Nanolipid }\end{array}$ & Intravenous & 82.5 & {$[160]$} \\
\hline \multirow[t]{6}{*}{ Lung } & 801D & 60 Cur & Intraperitoneal & ffi 50 & [161] \\
\hline & A459 & 15 Cur + 10 Docetaxel & Intravenous & ffi 70 & {$[164]$} \\
\hline & CL1-5 & 1000 Cur + 60 Gefitinib & Oral & ffi 70 & [165] \\
\hline & H1299 & 1000 Cur + 100 Gefitinib & Oral gavage & ffi 50 & [166] \\
\hline & H157 & 1000 Cur + 100 Gefitinib & Oral gavage & ffi 50 & {$[166]$} \\
\hline & A459 & 500 Cur + 200 Phospo-sulindac & Oral gavage & 51 & [168] \\
\hline \multirow[t]{4}{*}{ Prostate } & PC3-Luc & 100 Cur & Intraperitoneal & ffi 40 & {$[170]$} \\
\hline & C4-2B & 100 Cur +20 Nelfinavir +10 Docetaxel & Intraperitoneal & ffi 90 & {$[171]$} \\
\hline & DU-145 & 5 Cur & Oral gavage & ffi 40 & {$[174]$} \\
\hline & LNCaP & 30 Cur + 15 TRAIL & Oral & ffi 50 & {$[175]$} \\
\hline
\end{tabular}

${ }^{*}$ Percentage inhibition of tumor growth as compared to control (control is $0 \%$ inhibition)

Females) between ages 18-65 years with a randomized dosage of 50\% receiving single dose of $10 \mathrm{~g}$ and the remaining 50\% receiving $12 \mathrm{~g}$ of powdered extract of turmeric in capsules ${ }^{[175]}$. Reverse phase HPLC used for quantification showed no free curcumin in serum except for one candidate and high rate of covalent bonding of glucuronic acid and sulfation at phenolic - $\mathrm{OH}$ group in curcumin was observed. The adverse symptoms reported in this study were headache in one candidate, while one more candidate reported sore arms. However these symptoms are most unlikely to be caused by curcumin treatment. Three month long oral treatment of 25 high risk patients with different conditions including a gradual increase of 500 $\mathrm{mg} /$ day of curcumin upto $8 \mathrm{~g} /$ day, showed no adverse effects which could be associated with curcumin administration ${ }^{[176]}$. The serum level of curcumin was found to decrease with respect to time and the highest level of serum curcumin was detected within one or two hours of oral ingestion, where the patient receiving $8 \mathrm{~g}$ /day dose of curcumin showed $1.77 \pm 1.87 \mu \mathrm{M}$ curcumin in serum. The study showed that upto $8 \mathrm{~g}$ /day dose of curcumin did not show adverse effects and also showed improvement in precancerous lesions on histological examination.

A formulation of curcumin, Theracurmin tested on healthy volunteers showed improved bioavailability of curcumin with a peak plasma level of $0.74 \pm 0.18 \mu \mathrm{M}$ and $\mathrm{t}_{1 / 2}$ of $13.3 \mathrm{~h}$ for a single dose of $210 \mathrm{mg}^{[177]}$. 
Table 3. Clinical trials of Curcumin

\begin{tabular}{|c|c|c|c|c|c|c|}
\hline $\begin{array}{l}\text { Group } \\
\text { size }\end{array}$ & Formulation & $\begin{array}{l}\text { Health status of } \\
\text { volunteers }\end{array}$ & Dose per day & $\begin{array}{l}\text { Average peak serum/ } \\
\text { plasma concentration } \\
\text { in } \mu \mathbf{M}\end{array}$ & Remarks & Ref. \\
\hline$\overline{12}$ & $\begin{array}{l}\text { Powdered extract } \\
\text { of curcuminoids in } \\
\text { capsule }\end{array}$ & Healthy & $\begin{array}{l}10 \mathrm{~g}(\mathrm{~N}=6) \\
12 \mathrm{~g}(\mathrm{~N}=6)\end{array}$ & $\begin{array}{l}\text { No free curcumin was } \\
\text { detected in plasma }\end{array}$ & No adverse side effects & {$[175]$} \\
\hline 25 & Curcumin powder & $\begin{array}{l}\text { Patients with one of the } \\
\text { following conditions } \\
\text { a) recently resected urinary } \\
\text { bladder cancer } \\
\text { b) arsenic Bowen's disease } \\
\text { of the skin } \\
\text { c) uterine cervical } \\
\text { intraepithelial neoplasm } \\
\text { d) oral leukoplakia } \\
\text { e) intestinal metaplasia }\end{array}$ & $\begin{array}{l}4 g \\
6 g \\
8 g\end{array}$ & $\begin{array}{l}\text { Peak serum level (PSL) } \\
0.51 \pm 0.11 \\
0.63 \pm 0.06 \\
1.77 \pm 1.87\end{array}$ & $\begin{array}{l}\text { No adverse effect } \\
\text { and improvement in } \\
\text { precancerous lesions }\end{array}$ & {$[176]$} \\
\hline 06 & $\begin{array}{l}\text { Theracurmin } \\
\text { (nanoparticle } \\
\text { formulation) }\end{array}$ & Healthy & $\begin{array}{l}150 \mathrm{mg} \text { and } 210 \\
\mathrm{mg}\end{array}$ & $\begin{array}{l}\text { Peak plasma level (PPL) } \\
0.74 \pm 0.18\end{array}$ & $\begin{array}{l}\text { No adverse effect except } \\
\text { for one report of diarrhea } \\
\text { in one volunteer after a } \\
\text { single oral dose of } 150 \mathrm{mg}\end{array}$ & {$[177]$} \\
\hline 16 & $\begin{array}{l}\text { Theracurmin } \\
\text { (nanoparticle } \\
\text { formulation) in } 100 \\
\text { mL flavored drink }\end{array}$ & $\begin{array}{l}\text { Patients receiving } \\
\text { gemcitabine based therapy } \\
\text { for pancreatic cancer or } \\
\text { biliary tract cancer }\end{array}$ & $\begin{array}{l}200 \mathrm{mg}(\mathrm{N}=10) \\
400 \mathrm{mg}(\mathrm{N}=06)\end{array}$ & $\begin{array}{l}\text { PPL } \\
0.87 \\
1.19\end{array}$ & $\begin{array}{l}\text { Improvement in adverse } \\
\text { effect of chemotherapy }\end{array}$ & {$[178]$} \\
\hline 10 & $\begin{array}{l}\text { Curcumin in } \\
\text { chewing gum }\end{array}$ & Healthy & $2 \mathrm{~g}$ & $\begin{array}{l}P S L \\
0.45 \pm 0.17\end{array}$ & $\begin{array}{l}\text { Decreased levels of pro- } \\
\text { inflammatory marker } \\
\text { TNF- } \alpha \text { is observed }\end{array}$ & {$[179]$} \\
\hline 17 & $\begin{array}{l}\text { Solid-lipid } \\
\text { particles loaded } \\
\text { with curcumin in } \\
\text { capsule }\end{array}$ & $\begin{array}{l}06 \text { Healthy } \\
11 \text { Patients with metastatic } \\
\text { osteogenic sarcoma }\end{array}$ & $400 \mathrm{mg}$ to $1.6 \mathrm{~g}$ & $\begin{array}{l}\text { PPL at dose of } 1.6 \mathrm{~g} \\
0.11 \pm 0.024\end{array}$ & No adverse effects & {$[180]$} \\
\hline 25 & Caplet & $\begin{array}{l}\text { Advanced pancreatic cancer } \\
\text { already treated through } \\
\text { surgery or radiotherapy or } \\
\text { chemotherapy }\end{array}$ & $8 \mathrm{~g}$ & $\begin{array}{l}\text { PPL } \\
0.059 \text { to } 0.11\end{array}$ & $\begin{array}{l}\text { No adverse effect in the } \\
\text { participants and one } \\
\text { patient showed brief } \\
\text { reduction of } 73 \% \text { in tumor } \\
\text { volume }\end{array}$ & {$[181]$} \\
\hline
\end{tabular}

Theracurmin was administered in a group of 16 patients-undergoing gemcitabine-based chemotherapy for pancreatic cancer- in the form of $100 \mathrm{~mL}$ flavored drink with an initial dose of $200 \mathrm{mg}$ followed by doubling of dose in the absence of adverse side effects. The peak plasma levels was found to be $1.19 \mu \mathrm{M}$ with a dose of $400 \mathrm{mg} /$ day. The patients receiving Theracurmin showed improvement on adverse effects caused by chemotherapy and improvement in scores of quality-of-life ${ }^{[178]}$.

Healthy volunteers used formulation of curcumin in the form of gum administered over a period of $1 \mathrm{~h}$ with chewing and keeping the gum for 4 minutes against buccal mucosa. The peak serum concentration was recorded to be $0.45 \pm 0.17 \mu \mathrm{M}$ at $4 \mathrm{~h}$ with decreased levels of pro-inflammatory biomarkers TNF- $\alpha$ with $\sim 2 \mathrm{~g}$ of released curcumin ${ }^{[179]}$.

Eleven patients 7 males and 4 females in the age group of 12-26 years, suffering from advanced stage of metastatic osteogenic sarcoma and 6 healthy volunteers on treatment of solid-lipid particles loaded with curcumin in capsule form showed increased levels of curcumin in plasma and decreased level of TNF $\alpha^{[180]}$. No adverse effects were noticed in these patients, which could be correlated with curcumin consumption. The plasma levels of curcumin were constantly found to be in the range of $0.11 \pm 0.024 \mu \mathrm{M}$ in patients on treatment with the nanoformulation. In a Phase II clinical trial with 25 patients (median age 65 year) suffering from advanced pancreatic cancer already undergone surgery, radiotherapy or chemotherapy were treated with a daily oral dose of curcumin $(8 \mathrm{~g})$ in caplets for 8 weeks ${ }^{[181]}$. One patient showed a brief reduction of $73 \%$ in tumor and no adverse effect in all the patients and the peak plasma level of curcumin remained in the range 0.059 to $0.11 \mu \mathrm{M}$ for the one month duration. A summary of clinical trials of curcumin has been compiled in Table 3. 


\section{CONCLUSION}

Curcumin has shown commendable potential during in vitro and in vivo studies against vrious cancers. It has also been established through clinical trials that curcumin does not show any adverse effect upto a daily dose of $8 \mathrm{~g}$ to $12 \mathrm{~g}$. However, issues related to lower solubility, lower bioavailability and less stability in physiological conditions during human trials are yet to be resolved. Similar challenges have been overcome in case of taxol-a plant derived anticancer agent-which has now an FDA approved anticancer drug.

A biocompatible drug delivery system with a very safe toxicity profile may revolutionize the curcuminbased adjuvant chemotherapy with different roles in chemoprevention, chemo-sensitization and chemoprotection from adverse side effects of chemotherapeutic agents. The combinatorial treatment of curcumin has been shown to sensitize the drug-resistant cancer towards existing anticancer drugs and this aspect of combinatorial treatment can be exploited to fully utilize the curative potential of curcumin. In the near future, curcumin may play an important role in chemotherapeutic regimes against different types of cancers.

\section{DECLARATIONS}

\section{Acknowledgement}

The authors are thankful to the DST for FIST o Level Grants.

\section{Authors' contributions}

Made substantial contributions to conception and interpretation: Shaikh S, Yusufi M

Reference data collection and segregation: Shaikh J, Doke K, Ahmed K

Reference data collection and art work: Naba YS

\section{Availability of data and materials}

Not Applicable.

\section{Financial support and sponsorship}

None.

\section{Conflicts of interest}

All authors declared that there are no conflicts of interest.

\section{Ethical approval and consent to participate}

Not Applicable.

\section{Consent for publication}

Not Applicable.

\section{Copyright}

(c) The Author(s) 2021.

\section{REFERENCES}

1. Siegel RL, Miller KD, Jemal A. Cancer statistics, 2020. CA Cancer J Clin 2020;70:7-30.

2. Mansoori B, Mohammadi A, Davudian S, Shirjang S, Baradaran B. The different mechanisms of cancer drug resistance: a brief review. Adv Pharm Bull 2017;7:339-48.

3. Newman DJ, Cragg GM. Natural products as sources of new drugs from 1981 to 2014. J Nat Prod 2016;79:629-61.

4. Padhye S, Dandawate P, Yusufi M, Ahmad A, Sarkar FH. Perspectives on medicinal properties of plumbagin and its analogs. Med Res Rev 2012;32:1131-58. 
5. Gold M, Mujahid Y, Ahmed K, et al. A new 4-(pyridinyl)-4H-benzo[g]chromene-5,10-dione ruthenium(II) complex inducing senescence in 518A2 melanoma cells. J Biol Inorg Chem 2019;24:647-57.

6. Yusufi M, Banerjee S, Mohammad M, et al. Synthesis, characterization and anti-tumor activity of novel thymoquinone analogs against pancreatic cancer. Bioorg Med Chem Lett 2013;23:3101-4.

7. Subramaniam D, Kaushik G, Dandawate P, Anant S. Targeting cancer stem cells for chemoprevention of pancreatic cancer. Curr Med Chem 2018;25:2585-94.

8. Angulo P, Kaushik G, Subramaniam D, et al. Natural compounds targeting major cell signaling pathways: a novel paradigm for osteosarcoma therapy. J Hematol Oncol 2017;10:10.

9. Dandawate PR, Subramaniam D, Jensen RA, Anant S. Targeting cancer stem cells and signaling pathways by phytochemicals: novel approach for breast cancer therapy. Semin Cancer Biol 2016;40-41:192-208.

10. Dandawate PR, Vyas AC, Padhye SB, Singh MW, Baruah JB. Perspectives on medicinal properties of benzoquinone compounds. Mini Rev Med Chem 2010;10:436-54.

11. Dandawate P, Padhye S, Ahmad A, Sarkar FH. Novel strategies targeting cancer stem cells through phytochemicals and their analogs. Drug Deliv Transl Res 2013;3:165-82.

12. Dandawate P, Ahmed K, Padhye S, Ahmad A, Biersack B. Anticancer Active heterocyclic chalcones: recent developments. Anticancer Agents Med Chem 2020.

13. Vyas A, Dandawate P, Padhye S, Ahmad A, Sarkar F. Perspectives on new synthetic curcumin analogs and their potential anticancer properties. Curr Pharm Des 2013;19:2047-69.

14. Dandawate PR, Vyas A, Ahmad A et al. Inclusion complex of novel curcumin analogue CDF and beta-cyclodextrin (1:2) and its enhanced in vivo anticancer activity against pancreatic cancer. Pharm Res 2012;29:1775-86.

15. Nelson KM, Dahlin JL, Bisson J, Graham J, Pauli GF, Walters MA. The essential medicinal chemistry of curcumin. $J$ Med Chem 2017;60:1620-37.

16. Trinh HT, Bae EA, Lee JJ, Kim DH. Inhibitory effects of curcuminoids on passive cutaneous anaphylaxis reaction and scratching behavior in mice. Arch Pharm Res 2009;32:1783-7.

17. Abrahams S, Haylett WL, Johnson G, Carr JA, Bardien S. Antioxidant effects of curcumin in models of neurodegeneration, aging, oxidative and nitrosative stress: A review. Neuroscience 2019;406:1-21.

18. Azami SH, Nazarian H, Abdollahifar MA, Eini F, Farsani MA, Novin MG. The antioxidant curcumin postpones ovarian aging in young and middle-aged mice. Reprod Fertil Dev 2020;32:292-303.

19. Tanrıkulu-Küçük S, Başaran-Küçükgergin C, Seyithanoğlu M, et al. Effect of dietary curcumin and capsaicin on testicular and hepatic oxidant-antioxidant status in rats fed a high-fat diet. Appl Physiol Nutr Metab 2019;44:774-82.

20. Wafi AM, Hong J, Rudebush TL, et al. Curcumin improves exercise performance of mice with coronary artery ligation-induced HFrEF: Nrf2 and antioxidant mechanisms in skeletal muscle. J Appl Physiol (1985) 2019;126:477-86.

21. Bower MR, Aiyer HS, Li Y, Martin RC. Chemoprotective effects of curcumin in esophageal epithelial cells exposed to bile acids. World $J$ Gastroenterol 2010;16:4152-8.

22. Benzer F, Kandemir FM, Kucukler S, Comakli S, Caglayan C. Chemoprotective effects of curcumin on doxorubicin-induced nephrotoxicity in wistar rats: by modulating inflammatory cytokines, apoptosis, oxidative stress and oxidative DNA damage. Arch Physiol Biochem 2018;124:448-57.

23. Jagtap S, Meganathan K, Wagh V, Winkler J, Hescheler J, Sachinidis A. Chemoprotective mechanism of the natural compounds, epigallocatechin-3-O-gallate, quercetin and curcumin against cancer and cardiovascular diseases. Curr Med Chem 2009;16:1451-62.

24. Den Hartogh DJ, Gabriel A, Tsiani E. Antidiabetic properties of curcumin i: evidence from in vitro studies. Nutrients 2020;12:118.

25. Kostrzewa T, Przychodzen P, Gorska-Ponikowska M, Kuban-Jankowska A. Curcumin and cinnamaldehyde as PTP1B inhibitors with antidiabetic and anticancer potential. Anticancer Res 2019;39:745-9.

26. Gutierres VO, Campos ML, Arcaro CA, et al. Curcumin pharmacokinetic and pharmacodynamic evidences in streptozotocin-diabetic rats support the antidiabetic activity to be via metabolite(s). Evid Based Complement Alternat Med 2015;2015:678218.

27. Hesari A, Rezaei M, Rezaei M, et al. Effect of curcumin on glioblastoma cells. J Cell Physiol 2019;234:10281-8.

28. Falke J, Parkkinen J, Vaahtera L, Hulsbergen-van de Kaa CA, Oosterwijk E, Witjes JA. Curcumin as treatment for bladder cancer: a preclinical study of cyclodextrin-curcumin complex and bcg as intravesical treatment in an orthotopic bladder cancer rat model. Biomed Res Int 2018;2018:9634902.

29. Chen J, Qin X, Zhong S, Chen S, Su W, Liu Y. Characterization of curcumin/cyclodextrin polymer inclusion complex and investigation on its antioxidant and antiproliferative activities. Molecules 2018;23:1179.

30. Lou S, Wang Y, Yu Z, Guan K, Kan Q. Curcumin induces apoptosis and inhibits proliferation in infantile hemangioma endothelial cells via downregulation of MCL-1 and HIF-1 $\alpha$. Medicine (Baltimore) 2018;97:e9562.

31. Yu Z, Wan Y, Liu Y, Yang J, Li L, Zhang W. Curcumin induced apoptosis via PI3K/Akt-signalling pathways in SKOV3 cells. Pharm Biol 2016;54:2026-32.

32. Singh RK, Kumar S, Prasad DN, Bhardwaj TR. Therapeutic journery of nitrogen mustard as alkylating anticancer agents: historic to future perspectives. Eur J Med Chem 2018;151:401-33.

33. Madoc-Jones H, Mauro F. Interphase action of vinblastine and vincristine: differences in their lethal action through the mitotic cycle of cultured mammalian cells. J Cell Physiol 1968;72:185-96.

34. Quirke VM. Tamoxifen from failed contraceptive pill to best-selling breast cancer medicine: a case-study in pharmaceutical innovation. Front Pharmacol 2017;8:620. 
35. Anderson DR, Grillo-López A, Varns C, Chambers KS, Hanna N. Targeted anti-cancer therapy using rituximab, a chimaeric anti-CD20 antibody (IDEC-C2B8) in the treatment of non-Hodgkin's B-cell lymphoma. Biochem Soc Trans 1997;25:705-8.

36. Buchdunger E, Zimmermann $\mathrm{J}$, Mett $\mathrm{H}$ et al. Inhibition of the Abl protein-tyrosine kinase in vitro and in vivo by a 2-phenylaminopyrimidine derivative. Cancer Res 1996;56:100-4.

37. Gu Y, Zhang Z, Yin J, et al. Epigenetic silencing of miR-493 increases the resistance to cisplatin in lung cancer by targeting tongue cancer resistance-related protein 1(TCRP1). J Exp Clin Cancer Res 2017;36:114.

38. Koch J, Hau J, Jensen HE, Rieneck K. Cancer resistance as an acquired and inheritable trait. Anticancer Res 2014;34:6315-25.

39. Laszlo GS, Gudgeon CJ, Harrington KH, et al. Cellular determinants for preclinical activity of a novel CD33/CD3 bispecific T-cell engager (BiTE) antibody, AMG 330, against human AML. Blood 2014;123:554-61.

40. Krøll J. Estetrol, molecular chaperones, and the epigenetics of longevity and cancer resistance. Rejuvenation Res 2014;17:157-8.

41. Krøll J. Molecular chaperones and the epigenetics of longevity and cancer resistance. Ann N Y Acad Sci 2007;1100:75-83.

42. Marin JJ, Briz O, Rodríguez-Macias G, Díez-Martín JL, Macias RI. Role of drug transport and metabolism in the chemoresistance of acute myeloid leukemia. Blood Rev 2016;30:55-64.

43. Kartal-Yandim M, Adan-Gokbulut A, Baran Y. Molecular mechanisms of drug resistance and its reversal in cancer. Crit Rev Biotechnol 2016;36:716-26.

44. Gottesman MM, Lavi O, Hall MD, Gillet JP. Toward a Better Understanding of the Complexity of Cancer Drug Resistance. Annu Rev Pharmacol Toxicol 2016;56:85-102.

45. Pawlowska E, Blasiak J. DNA repair--a double-edged sword in the genomic stability of cancer cells--the case of chronic myeloid leukemia. Int J Mol Sci 2015;16:27535-49.

46. Wieringa HW, van der Zee AG, de Vries EG, van Vugt MA. Breaking the DNA damage response to improve cervical cancer treatment. Cancer Treat Rev 2016;42:30-40.

47. Mohammad RM, Muqbil I, Lowe L, et al. Broad targeting of resistance to apoptosis in cancer. Semin Cancer Biol 2015;35 Suppl:S78-S103.

48. Wilson TR, Johnston PG, Longley DB. Anti-apoptotic mechanisms of drug resistance in cancer. Curr Cancer Drug Targets 2009;9:307-19.

49. Pommier Y, Sordet O, Antony S, Hayward RL, Kohn KW. Apoptosis defects and chemotherapy resistance: molecular interaction maps and networks. Oncogene 2004;23:2934-49.

50. Nantajit D, Lin D, Li JJ. The network of epithelial-mesenchymal transition: potential new targets for tumor resistance. J Cancer Res Clin Oncol 2015;141:1697-713.

51. Tsukasa K, Ding Q, Yoshimitsu M, Miyazaki Y, Matsubara S, Takao S. Slug contributes to gemcitabine resistance through epithelialmesenchymal transition in CD133(+) pancreatic cancer cells. Hum Cell 2015;28:167-74.

52. Huang J, Li H, Ren G. Epithelial-mesenchymal transition and drug resistance in breast cancer (Review). Int J Oncol 2015;47:840-8.

53. Mehta K, Pantazis P, McQueen T, Aggarwal BB. Antiproliferative effect of curcumin (diferuloylmethane) against human breast tumor cell lines. Anticancer Drugs 1997;8:470-81.

54. Ramachandran C, You W. Differential sensitivity of human mammary epithelial and breast carcinoma cell lines to curcumin. Breast Cancer Res Treat 1999;54:269-78.

55. Meiyanto E, Putri DD, Susidarti RA, et al. Curcumin and its analogues (PGV-0 and PGV-1) enhance sensitivity of resistant MCF-7 cells to doxorubicin through inhibition of HER2 and NF-kB activation. Asian Pac J Cancer Prev 2014;15:179-84.

56. Jiang $\mathrm{M}$, Huang $\mathrm{O}$, Zhang $\mathrm{X}$, et al. Curcumin induces cell death and restores tamoxifen sensitivity in the antiestrogen-resistant breast cancer cell lines MCF-7/LCC2 and MCF-7/LCC9. Molecules 2013;18:701-20.

57. Muniyandi K, George B, Parimelazhagan T, Abrahamse H. Role of photoactive phytocompounds in photodynamic therapy of cancer. Molecules 2020;25:4102.

58. Li Y, Xiao P, Huang ZP, et al. Evaluation of curcumin-mediated photodynamic therapy on the reverse of multidrug resistance in tumor cells. RSC Adv 2020;10:298-306.

59. Shakibaei M, Buhrmann C, Kraehe P, Shayan P, Lueders C, Goel A. Curcumin chemosensitizes 5-fluorouracil resistant MMR-deficient human colon cancer cells in high density cultures. PLoS One 2014;9:e85397.

60. Shakibaei M, Mobasheri A, Lueders C, Busch F, Shayan P, Goel A. Curcumin enhances the effect of chemotherapy against colorectal

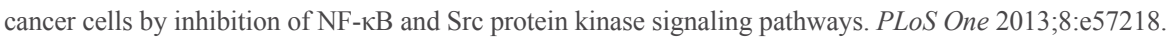

61. Ruiz de Porras V, Bystrup S, Martínez-Cardús A, et al. Curcumin mediates oxaliplatin-acquired resistance reversion in colorectal cancer cell lines through modulation of CXC-Chemokine/NF-kB signalling pathway. Sci Rep 2016;6:24675.

62. Rao J, Xu DR, Zheng FM, et al. Curcumin reduces expression of Bcl-2, leading to apoptosis in daunorubicin-insensitive CD34+ acute myeloid leukemia cell lines and primary sorted CD34+ acute myeloid leukemia cells. J Transl Med 2011;9:71.

63. Li N, Wen S, Chen G, Wang S. Antiproliferative potential of piperine and curcumin in drug-resistant human leukemia cancer cells are mediated via autophagy and apoptosis induction, S-phase cell cycle arrest and inhibition of cell invasion and migration. $J B U O N$ 2020;25:401-6.

64. Lee J, Im YH, Jung HH, et al. Curcumin inhibits interferon-alpha induced NF-kappaB and COX-2 in human A549 non-small cell lung cancer cells. Biochem Biophys Res Commun 2005;334:313-8.

65. Gu Y, Li J, Li Y, et al. Nanomicelles loaded with doxorubicin and curcumin for alleviating multidrug resistance in lung cancer. Int $J$ Nanomedicine 2016;11:5757-70.

66. Hussain AR, Al-Rasheed M, Manogaran PS, et al. Curcumin induces apoptosis via inhibition of PI3'-kinase/AKT pathway in acute T cell leukemias. Apoptosis 2006;11:245-54. 
67. Kuttikrishnan S, Siveen KS, Prabhu KS, et al. Curcumin induces apoptotic cell death via inhibition of PI3-Kinase/AKT pathway in B-precursor acute lymphoblastic leukemia. Front Oncol 2019;9:484.

68. Deeb D, Jiang H, Gao X et al. Curcumin sensitizes prostate cancer cells to tumor necrosis factor-related apoptosis-inducing ligand/Apo2L by inhibiting nuclear factor-kappaB through suppression of IkappaBalpha phosphorylation. Mol Cancer Ther 2004;3:803-12.

69. Mathur A, Abd Elmageed ZY, Liu X, et al. Subverting ER-stress towards apoptosis by nelfinavir and curcumin coexposure augments docetaxel efficacy in castration resistant prostate cancer cells. PLoS One 2014;9:e103109.

70. Tanaudommongkon I, Tanaudommongkon A, Prathipati P, Nguyen JT, Keller ET, Dong X. Curcumin nanoparticles and their cytotoxicity in docetaxel-resistant castration-resistant prostate cancer cells. Biomedicines 2020;8:253.

71. Matsui W, Huff CA, Wang Q, et al. Characterization of clonogenic multiple myeloma cells. Blood 2004;103:2332-6.

72. Al-Hajj M, Clarke MF. Self-renewal and solid tumor stem cells. Oncogene 2004;23:7274-82.

73. Boman BM, Wicha MS. Cancer stem cells: a step toward the cure. J Clin Oncol 2008;26:2795-9.

74. Huntly BJ, Gilliland DG. Leukaemia stem cells and the evolution of cancer-stem-cell research. Nat Rev Cancer 2005;5:311-21.

75. Kanwar SS, Yu Y, Nautiyal J, Patel BB, Majumdar AP. The Wnt/beta-catenin pathway regulates growth and maintenance of colonospheres. Mol Cancer 2010;9:212.

76. Kessler M, Hoffmann K, Brinkmann V, et al. The Notch and Wnt pathways regulate stemness and differentiation in human fallopian tube organoids. Nat Commun 2015;6:8989.

77. Milla LA, González-Ramírez CN, Palma V. Sonic Hedgehog in cancer stem cells: a novel link with autophagy. Biol Res 2012;45:223-30.

78. Cochrane CR, Szczepny A, Watkins DN, Cain JE. Hedgehog signaling in the maintenance of cancer stem cells. Cancers (Basel) 2015; 7:1554-85

79. Park JH, Shin JE, Park HW. The role of hippo pathway in cancer stem cell biology. Mol Cells 2018;41:83-92.

80. Mo JS, Park HW, Guan KL. The Hippo signaling pathway in stem cell biology and cancer. EMBO Rep 2014;15:642-56.

81. MacDonald BT, Tamai K, He X. Wnt/beta-catenin signaling: components, mechanisms, and diseases. Dev Cell 2009;17:9-26.

82. Logan CY, Nusse R. The Wnt signaling pathway in development and disease. Annu Rev Cell Dev Biol 2004;20:781-810.

83. Dihlmann S, von Knebel Doeberitz M. Wnt/beta-catenin-pathway as a molecular target for future anti-cancer therapeutics. Int $J$ Cancer 2005;113:515-24.

84. Smalley MJ, Dale TC. Wnt signalling in mammalian development and cancer. Cancer Metastasis Rev 1999;18:215-30.

85. Barker N, Clevers H. Mining the Wnt pathway for cancer therapeutics. Nat Rev Drug Discov 2006;5:997-1014.

86. Paul S, Dey A. Wnt signaling and cancer development: therapeutic implication. Neoplasma 2008;55:165-76.

87. Pan Y, Sun Y, Liu Z, Zhang C. miR-192-5p upregulation mediates the suppression of curcumin in human NSCLC cell proliferation, migration and invasion by targeting c-Myc and inactivating the Wnt/ $\beta$-catenin signaling pathway. Mol Med Rep 2020;22:1594-604.

88. He M, Li Y, Zhang L, et al. Curcumin suppresses cell proliferation through inhibition of the Wnt/ $\beta$-catenin signaling pathway in medulloblastoma. Oncol Rep 2014;32:173-80.

89. Jaiswal AS, Marlow BP, Gupta N, Narayan S. Beta-catenin-mediated transactivation and cell-cell adhesion pathways are important in curcumin (diferuylmethane)-induced growth arrest and apoptosis in colon cancer cells. Oncogene 2002;21:8414-27.

90. Narayan S. Curcumin, a multi-functional chemopreventive agent, blocks growth of colon cancer cells by targeting $\beta$-catenin-mediated transactivation and cell-cell adhesion pathways. Histochem J 2003;35:301-7.

91. Park CH, Hahm ER, Park S, Kim HK, Yang CH. The inhibitory mechanism of curcumin and its derivative against beta-catenin/Tcf signaling. FEBS Lett 2005;579:2965-71.

92. Simpson F, Kerr MC, Wicking C. Trafficking, development and hedgehog. Mech Dev 2009;126:279-88.

93. Tasouri E, Tucker KL. Primary cilia and organogenesis: is Hedgehog the only sculptor? Cell Tissue Res 2011;345:21-40.

94. Beachy PA, Karhadkar SS, Berman DM. Tissue repair and stem cell renewal in carcinogenesis. Nature 2004;432:324-31.

95. Slusarz A, Shenouda NS, Sakla MS, et al. Common botanical compounds inhibit the hedgehog signaling pathway in prostate cancer. Cancer Res 2010;70:3382-90.

96. Sun XD, Liu XE, Huang DS. Curcumin reverses the epithelial-mesenchymal transition of pancreatic cancer cells by inhibiting the Hedgehog signaling pathway. Oncol Rep 2013;29:2401-7.

97. Cao L, Xiao X, Lei J, Duan W, Ma Q, Li W. Curcumin inhibits hypoxia-induced epithelial-mesenchymal transition in pancreatic cancer cells via suppression of the hedgehog signaling pathway. Oncol Rep 2016;35:3728-34.

98. Bahrami A, Majeed M, Sahebkar A. Curcumin: a potent agent to reverse epithelial-to-mesenchymal transition. Cell Oncol (Dordr) 2019;42:405-21.

99. Wang D, Kong X, Li Y, et al. Curcumin inhibits bladder cancer stem cells by suppressing Sonic Hedgehog pathway. Biochem Biophys Res Commun 2017;493:521-7.

100. Elamin MH, Shinwari Z, Hendrayani SF, et al. Curcumin inhibits the Sonic Hedgehog signaling pathway and triggers apoptosis in medulloblastoma cells. Mol Carcinog 2010;49:302-14.

101. Hori K, Sen A, Artavanis-Tsakonas S. Notch signaling at a glance. J Cell Sci 2013;126:2135-40.

102. Colombo M, Mirandola L, Platonova N, et al. Notch-directed microenvironment reprogramming in myeloma: a single path to multiple outcomes. Leukemia 2013;27:1009-18.

103. Olsauskas-Kuprys R, Zlobin A, Osipo C. Gamma secretase inhibitors of Notch signaling. Onco Targets Ther 2013;6:943-55.

104. Rizzo P, Osipo C, Foreman K, Golde T, Osborne B, Miele L. Rational targeting of Notch signaling in cancer. Oncogene 2008;27:5124-31.

105. Subramaniam D, Ponnurangam S, Ramamoorthy P, et al. Curcumin induces cell death in esophageal cancer cells through modulating Notch signaling. PLoS One 2012; 7:e30590. 
106. Wang J, Sullenger BA, Rich JN. Notch Signaling in Cancer Stem Cells. In: Reichrath J, Reichrath S, editors. Notch Signaling in Embryology and Cancer. New York: Springer US; 2012. pp. 174-85.

107. Yang Y, Duan W, Liang Z, et al. Curcumin attenuates endothelial cell oxidative stress injury through Notch signaling inhibition. Cell Signal 2013;25:615-29.

108. Zhao NJ, Liao MJ, Wu JJ, Chu KX. Curcumin suppresses Notch-1 signaling: improvements in fatty liver and insulin resistance in rats. Mol Med Rep 2018;17:819-26.

109. He G, Mu T, Yuan Y, et al. Effects of notch signaling pathway in cervical cancer by curcumin mediated photodynamic therapy and its possible mechanisms in vitro and in vivo. J Cancer 2019;10:4114-22.

110. Cheng C, Sui B, Wang M, Hu X, Shi S, Xu P. Carrier-free nanoassembly of curcumin-erlotinib conjugate for cancer targeted therapy. Adv Healthc Mater 2020;9:e2001128.

111. Tatiparti K, Rauf MA, Sau S, Iyer AK. Carbonic anhydrase-ix guided albumin nanoparticles for hypoxia-mediated triple-negative breast cancer cell killing and imaging of patient-derived tumor. Molecules 2020;25:2362.

112. Yallapu MM, Ebeling MC, Khan S, et al. Novel curcumin-loaded magnetic nanoparticles for pancreatic cancer treatment. Mol Cancer Ther 2013;12:1471-80.

113. Bisht S, Mizuma M, Feldmann G, et al. Systemic administration of polymeric nanoparticle-encapsulated curcumin (NanoCurc) blocks tumor growth and metastases in preclinical models of pancreatic cancer. Mol Cancer Ther 2010;9:2255-64.

114. Dhule SS, Penfornis P, He J, et al. The combined effect of encapsulating curcumin and C6 ceramide in liposomal nanoparticles against osteosarcoma. Mol Pharm 2014;11:417-27.

115. Dhule SS, Penfornis P, Frazier T, et al. Curcumin-loaded $\gamma$-cyclodextrin liposomal nanoparticles as delivery vehicles for osteosarcoma. Nanomedicine 2012;8:440-51.

116. Batra H, Pawar S, Bahl D. Curcumin in combination with anti-cancer drugs: A nanomedicine review. Pharmacol Res 2019;139:91-105.

117. Obaidi I, Cassidy H, Gaspar VI, et al. Curcumin sensitizes kidney cancer cells to TRAIL-induced apoptosis via ROS mediated activation of JNK-CHOP pathway and upregulation of DR4. Biology (Basel) 2020;9:92.

118. Sak K. Radiosensitizing potential of curcumin in different cancer models. Nutr Cancer 2020;72:1276-89.

119. Giladi N, Kazanov D, Shpitz B, Aroch I, Kraus S, Arber N. Curcumin potentiates the pro-apoptotic effects of sulindac sulfone in colorectal cancer. Expert Opin Investig Drugs 2010;19 Suppl 1:S117-24.

120. Shin GH, Li J, Cho JH, Kim JT, Park HJ. Enhancement of curcumin solubility by phase change from crystalline to amorphous in CurTPGS nanosuspension. J Food Sci 2016;81:N494-501.

121. Perry MC, Demeule M, Régina A, Moumdjian R, Béliveau R. Curcumin inhibits tumor growth and angiogenesis in glioblastoma xenografts. Mol Nutr Food Res 2010;54:1192-201.

122. Lee SJ, Krauthauser C, Maduskuie V, Fawcett PT, Olson JM, Rajasekaran SA. Curcumin-induced HDAC inhibition and attenuation of medulloblastoma growth in vitro and in vivo. BMC Cancer 2011;11:144.

123. Lim GP, Chu T, Yang F, Beech W, Frautschy SA, Cole GM. The curry spice curcumin reduces oxidative damage and amyloid pathology in an Alzheimer transgenic mouse. J Neurosci 2001;21:8370-7.

124. Purkayastha S, Berliner A, Fernando SS, et al. Curcumin blocks brain tumor formation. Brain Res 2009;1266:130-8.

125. Spiller SE, Logsdon NJ, Deckard LA, Sontheimer H. Inhibition of nuclear factor kappa-B signaling reduces growth in medulloblastoma in vivo. BMC Cancer 2011;11:136.

126. Aoki H, Takada Y, Kondo S, Sawaya R, Aggarwal BB, Kondo Y. Evidence that curcumin suppresses the growth of malignant gliomas in vitro and in vivo through induction of autophagy: role of Akt and extracellular signal-regulated kinase signaling pathways. Mol Pharmacol 2007;72:29-39.

127. Lv ZD, Liu XP, Zhao WJ et al. Curcumin induces apoptosis in breast cancer cells and inhibits tumor growth in vitro and in vivo. Int $J$ Clin Exp Pathol 2014;7(6):2818-2824.

128. Anand K, Sarkar A, Kumar A, Ambasta RK, Kumar P. Combinatorial antitumor effect of naringenin and curcumin elicit angioinhibitory activities in vivo. Nutr Cancer 2012;64:714-24.

129. Ferreira LC, Arbab AS, Jardim-Perassi BV, et al. Effect of curcumin on pro-angiogenic factors in the xenograft model of breast cancer. Anticancer Agents Med Chem 2015;15:1285-96.

130. García-Quiroz J, García-Becerra R, Santos-Cuevas C, et al. Synergistic antitumorigenic activity of calcitriol with curcumin or resveratrol is mediated by angiogenesis inhibition in triple negative breast cancer xenografts. Cancers (Basel) 2019;11:1739.

131. Chen W, Li L, Zhang X, et al. Curcumin: a calixarene derivative micelle potentiates anti-breast cancer stem cells effects in xenografted, triple-negative breast cancer mouse models. Drug Deliv 2017;24:1470-81.

132. Xiong K, Zhang Y, Wen Q, et al. Co-delivery of paclitaxel and curcumin by biodegradable polymeric nanoparticles for breast cancer chemotherapy. Int J Pharm 2020;589:119875.

133. Lai HW, Chien SY, Kuo SJ, et al. The potential utility of curcumin in the treatment of HER-2-overexpressed breast cancer: an in vitro and in vivo comparison study with herceptin. Evid Based Complement Alternat Med 2012;2012:486568.

134. Mukerjee A, Ranjan AP, Vishwanatha JK. Targeted nanocurcumin therapy using annexin A2 anitbody improves tumor accumulation and therapeutic efficacy against highly metastatic breast cancer. J Biomed Nanotechnol 2016;12:1374-92.

135. Ashkbar A, Rezaei F, Attari F, Ashkevarian S. Treatment of breast cancer in vivo by dual photodynamic and photothermal approaches with the aid of curcumin photosensitizer and magnetic nanoparticles. Sci Rep 2020;10:21206.

136. Aqil F, Munagala R, Jeyabalan J, Agrawal AK, Gupta R. Exosomes for the enhanced tissue bioavailability and efficacy of curcumin. AAPS J 2017;19:1691-702. 
137. Sreekanth CN, Bava SV, Sreekumar E, Anto RJ. Molecular evidences for the chemosensitizing efficacy of liposomal curcumin in paclitaxel chemotherapy in mouse models of cervical cancer. Oncogene 2011;30:3139-52.

138. Ahmed MB, Islam SU, Sonn JK, Lee YS. PRP4 kinase domain loss nullifies drug resistance and epithelial-mesenchymal transition in human colorectal carcinoma cells. Mol Cells 2020;43:662-70.

139. Kim TH, Jiang HH, Youn YS, et al. Preparation and characterization of water-soluble albumin-bound curcumin nanoparticles with improved antitumor activity. Int J Pharm 2011;403:285-91.

140. Howells LM, Sale S, Sriramareddy SN, et al. Curcumin ameliorates oxaliplatin-induced chemoresistance in HCT116 colorectal cancer cells in vitro and in vivo. Int $J$ Cancer 2011;129:476-86.

141. Guo LD, Shen YQ, Zhao XH, et al. Curcumin combined with oxaliplatin effectively suppress colorectal carcinoma in vivo through inducing apoptosis. Phytother Res 2015;29:357-65.

142. Alizadeh AM, Khaniki M, Azizian S, Mohaghgheghi MA, Sadeghizadeh M, Najafi F. Chemoprevention of azoxymethane-initiated colon cancer in rat by using a novel polymeric nanocarrier--curcumin. Eur J Pharmacol 2012;689:226-32.

143. Farhana L, Sarkar S, Nangia-Makker P, et al. Natural agents inhibit colon cancer cell proliferation and alter microbial diversity in mice. PLoS One 2020;15:e229823.

144. Zhou X, Wang W, Li P, et al. Curcumin enhances the effects of 5-Fluorouracil and oxaliplatin in inducing gastric cancer cell apoptosis both in vitro and in vivo. Oncol Res 2016;23:29-34.

145. Young NA, Bruss MS, Gardner M, et al. Oral administration of nano-emulsion curcumin in mice suppresses inflammatory-induced NFkB signaling and macrophage migration. PLoS One 2014;9:e111559.

146. Lin X, Wang L, Zhao L, et al. Curcumin micelles suppress gastric tumor cell growth by upregulating ROS generation, disrupting redox equilibrium and affecting mitochondrial bioenergetics. Food Funct 2020;11:4146-59.

147. Jiang H, Geng D, Liu H, Li Z, Cao J. Co-delivery of etoposide and curcumin by lipid nanoparticulate drug delivery system for the treatment of gastric tumors. Drug Deliv 2016;23:3665-73.

148. Clark CA, McEachern MD, Shah SH, et al. Curcumin inhibits carcinogen and nicotine-induced Mammalian target of rapamycin pathway activation in head and neck squamous cell carcinoma. Cancer Prev Res (Phila) 2010;3:1586-95.

149. Wang D, Veena MS, Stevenson K, et al. Liposome-encapsulated curcumin suppresses growth of head and neck squamous cell carcinoma in vitro and in xenografts through the inhibition of nuclear factor kappaB by an AKT-independent pathway. Clin Cancer Res 2008;14:6228-36.

150. Wang L, Wang W, Rui Z, Zhou D. The effective combination therapy against human osteosarcoma: doxorubicin plus curcumin coencapsulated lipid-coated polymeric nanoparticulate drug delivery system. Drug Deliv 2016;23:3200-8.

151. Karavasili C, Andreadis DA, Katsamenis OL, et al. Synergistic antitumor potency of a self-assembling peptide hydrogel for the local codelivery of doxorubicin and curcumin in the treatment of head and neck cancer. Mol Pharm 2019;16:2326-41.

152. Tian F, Zhang C, Tian W, Jiang Y, Zhang X. Comparison of the effect of p65 siRNA and curcumin in promoting apoptosis in esophageal squamous cell carcinoma cells and in nude mice. Oncol Rep 2012;28:232-40.

153. Pan Z, Zhuang J, Ji C, Cai Z, Liao W, Huang Z. Curcumin inhibits hepatocellular carcinoma growth by targeting VEGF expression. Oncol Lett 2018;15:4821-6.

154. Xu T, Guo P, Pi C, et al. Synergistic effects of curcumin and 5-Fluorouracil on the hepatocellular carcinoma in vivo and vitro through regulating the expression of COX-2 and NF-KB. J Cancer 2020;11:3955-64.

155. Hu P, Ke C, Guo X, et al. Both glypican-3/Wnt/ $/$-catenin signaling pathway and autophagy contributed to the inhibitory effect of curcumin on hepatocellular carcinoma. Dig Liver Dis 2019;51:120-6.

156. Zhang HH, Zhang Y, Cheng YN, et al. Metformin incombination with curcumin inhibits the growth, metastasis, and angiogenesis of hepatocellular carcinoma in vitro and in vivo. Mol Carcinog 2018;57:44-56.

157. Bortel N, Armeanu-Ebinger S, Schmid E, et al. Effects of curcumin in pediatric epithelial liver tumors: inhibition of tumor growth and alpha-fetoprotein in vitro and in vivo involving the NFkappaB- and the beta-catenin pathways. Oncotarget 2015;6:40680-91.

158. Lin KT, Wang YW, Chen CT, Ho CM, Su WH, Jou YS. HDAC inhibitors augmented cell migration and metastasis through induction of PKCs leading to identification of low toxicity modalities for combination cancer therapy. Clin Cancer Res 2012;18:4691-701.

159. Khor TO, Keum YS, Lin W, et al. Combined inhibitory effects of curcumin and phenethyl isothiocyanate on the growth of human PC-3 prostate xenografts in immunodeficient mice. Cancer Res 2006;66:613-21.

160. Yan J, Wang Y, Zhang X, Liu S, Tian C, Wang H. Targeted nanomedicine for prostate cancer therapy: docetaxel and curcumin coencapsulated lipid-polymer hybrid nanoparticles for the enhanced anti-tumor activity in vitro and in vivo. Drug Deliv 2016;23:1757-62.

161. Chen QY, Zheng Y, Jiao DM, et al. Curcumin inhibits lung cancer cell migration and invasion through Rac1-dependent signaling pathway. J Nutr Biochem 2014;25:177-85.

162. Chen QY, Jiao DM, Yao QH, et al. Expression analysis of Cdc42 in lung cancer and modulation of its expression by curcumin in lung cancer cell lines. Int J Oncol 2012;40:1561-8.

163. Garbuzenko OB, Winkler J, Tomassone MS, Minko T. Biodegradable Janus nanoparticles for local pulmonary delivery of hydrophilic and hydrophobic molecules to the lungs. Langmuir 2014;30:12941-9.

164. Yin H, Guo R, Xu Y, et al. Synergistic antitumor efficiency of docetaxel and curcumin against lung cancer. Acta Biochim Biophys Sin (Shanghai) 2012;44:147-53.

165. Lee JY, Lee YM, Chang GC, et al. Curcumin induces EGFR degradation in lung adenocarcinoma and modulates p38 activation in intestine: the versatile adjuvant for gefitinib therapy. PLoS One 2011;6:e23756.

166. Chen P, Huang HP, Wang Y, et al. Curcumin overcome primary gefitinib resistance in non-small-cell lung cancer cells through inducing 
autophagy-related cell death. J Exp Clin Cancer Res 2019;38:254.

167. Ibrahim A, El-Meligy A, Fetaih H, Dessouki A, Stoica G, Barhoumi R. Effect of curcumin and Meriva on the lung metastasis of murine mammary gland adenocarcinoma. In Vivo 2010;24:401-8.

168. Cheng KW, Wong CC, Mattheolabakis G, Xie G, Huang L, Rigas B. Curcumin enhances the lung cancer chemopreventive efficacy of phospho-sulindac by improving its pharmacokinetics. Int J Oncol 2013;43:895-902.

169. Ranjan AP, Mukerjee A, Gdowski A, et al. Curcumin-ER prolonged subcutaneous delivery for the treatment of non-small cell lung cancer. J Biomed Nanotechnol 2016;12:679-88.

170. Cheng TS, Chen WC, Lin YY, et al. Curcumin-targeting pericellular serine protease matriptase role in suppression of prostate cancer cell invasion, tumor growth, and metastasis. Cancer Prev Res (Phila) 2013;6:495-505.

171. Yu XL, Jing T, Zhao H, Li PJ, Xu WH, Shang FF. Curcumin inhibits expression of inhibitor of DNA binding 1 in PC3 cells and xenografts. Asian Pac J Cancer Prev 2014;15:1465-70.

172. Sundram V, Chauhan SC, Ebeling M, Jaggi M. Curcumin attenuates $\beta$-catenin signaling in prostate cancer cells through activation of protein kinase D1. PLoS One 2012;7:e35368.

173. Hong JH, Ahn KS, Bae E, Jeon SS, Choi HY. The effects of curcumin on the invasiveness of prostate cancer in vitro and in vivo. Prostate Cancer Prostatic Dis 2006;9:147-52.

174. Shankar S, Ganapathy S, Chen Q, Srivastava RK. Curcumin sensitizes TRAIL-resistant xenografts: molecular mechanisms of apoptosis, metastasis and angiogenesis. Mol Cancer 2008;7:16.

175. Vareed SK, Kakarala M, Ruffin MT, et al. Pharmacokinetics of curcumin conjugate metabolites in healthy human subjects. Cancer Epidemiol Biomarkers Prev 2008;17:1411-7.

176. Cheng AL, Hsu CH, Lin JK, et al. Phase I clinical trial of curcumin, a chemopreventive agent, in patients with high-risk or pre-malignant lesions. Anticancer Res 2001;21:2895-900.

177. Kanai M, Imaizumi A, Otsuka Y, et al. Dose-escalation and pharmacokinetic study of nanoparticle curcumin, a potential anticancer agent with improved bioavailability, in healthy human volunteers. Cancer Chemother Pharmacol 2012;69:65-70.

178. Kanai M, Otsuka Y, Otsuka K, et al. A phase I study investigating the safety and pharmacokinetics of highly bioavailable curcumin (Theracurmin) in cancer patients. Cancer Chemother Pharmacol 2013;71:1521-30.

179. Boven L, Holmes SP, Latimer B, et al. Curcumin gum formulation for prevention of oral cavity head and neck squamous cell carcinoma. Laryngoscope 2019;129:1597-603.

180. Gota VS, Maru GB, Soni TG, Gandhi TR, Kochar N, Agarwal MG. Safety and pharmacokinetics of a solid lipid curcumin particle formulation in osteosarcoma patients and healthy volunteers. J Agric Food Chem 2010;58:2095-9.

181. Dhillon N, Aggarwal BB, Newman RA, et al. Phase II trial of curcumin in patients with advanced pancreatic cancer. Clin Cancer Res 2008;14:4491-9. 